DOI: 10.20472/IAC.2018.038.015

JOHN HICKS

Charles Sturt University, Australia

\author{
GIRIJASANKAR MALLIK \\ University of Western Sydney, Australia
}

PARIKSHIT BASU

Charles Sturt University, Australia

\title{
EARNINGS OUTCOMES IN METROPOLITAN AND REGIONAL LABOUR MARKETS- A GENDER-BASED ANALYSIS FOR NEW SOUTH WALES AND VICTORIA
}

\begin{abstract}
:
It is generally accepted that the key characteristics of labour markets in Australian capital cities differ from those of the labour markets in the rest of Australia although labour market policy is typically conducted at the national level without taking regional differences into account. Gender issues have frequently been highlighted in the many analyses of urban Australian labour markets. Other studies have focused on the urban-regional dichotomy of the labour market. However, although studies of labour market features and outcomes in Australia have focused on issues related to location or gender, they rarely address both. This paper seeks to establish if discrimination by gender differs between regional and urban communities in the Australian context. The conceptual framework used in this research is in the tradition of human capital analysis. We first analyse, separately, determinants of hourly wage rates and weekly incomes by gender in Australian metropolitan cities and regional areas. We then utilise the Blinder-Oaxaca procedure, to decompose the mean outcome differences between men and women within a region into that part that is 'explained' by gender differences in endowments and that part which remains unexplained by such differences and which therefore provides a measure of discrimination. The data is drawn from individual level confidentialised unit record files (CURF) data of the 2006 Australian Census. Gender-based analysis is conducted for each region, Sydney, regional NSW, Melbourne and regional Victoria, with a view to discerning if the impact of the determinants vary spacially. The research confirmed that gender plays an important role in influencing labour market outcomes. The research also identified a number of factors that impact on both hourly wages and weekly earnings and assessed how these factors impacted differently for men and women across metropolitan and regional areas. The results indicate that, in general, differences exist between men and women in hourly wage rate and weekly income earned. The determinants of these differences varied between metropolitan cities and regional areas. With respect to issues of gender discrimination in employment, the use of the Blinder-Oaxaca decomposition technique confirmed the presence of discrimination against women in all regions. Wage discrimination is more pronounced in metropolitan areas whilst discrimination in weekly earnings is more important in non-metropolitan areas. The latter discrimination is likely to reflect both fewer job opportunities for women and a lower ownership of income earning assets by women.
\end{abstract}

\section{Keywords:}

Australian labour markets; discrimination against women; rural disadvantage 
JEL Classification: J70 


\section{Introduction}

The characteristics of geographically distinct labour markets differ across regions according to industry, demographic, social, professional, educational and other features. Australia is comprised of a few large metropolitan cities amidst a vast regional and rural landscape. It is generally accepted that the key characteristics of labour markets in these large cities differ from those of the labour markets in the rest of Australia although labour market policy is typically conducted at the national level without taking regional differences into account. To a certain extent this is understandable as the majority of the Australian population lives in these large metropolitan cities and their peripheries. Thus, it is not surprising that economic, social and political attention is focussed primarily on the issues of concern in the labour markets of these cities - often to the neglect of problems occurring elsewhere.

Studies on labour market features and outcomes in Australia have focused on issues related to location or gender, but rarely address both issues together. Despite the fact that gender has been considered as one of the factors that influence regional labour market outcomes, it is not frequently used as the basis of regional analysis. That is, in studying gender issues, researchers usually do not investigate how gender issues may vary spacially. Thus, there is a need to assess whether the level of discrimination against women in the labour force is higher or lower in regions as compared to metropolitan cities. It is also important to identify the factors that may cause or influence such differences.

The primary objective of this research is to analyse gender and location issues together in the context of the Australian labour market. This paper analyses the determinants of hourly wage rates and weekly incomes by gender in Australian metropolitan cities and regional areas utilising labour market data from two major metropolitan cities, Sydney (SYD) and Melbourne (MELB), and respective regional areas - regional NSW (RNSW) and regional Victoria (RVIC). The data is drawn from individual level confidentialised unit record files (CURF) data of the 2006 Census. Gender-based analysis is conducted for each region with a view to discerning if the impacts of the determinants vary spacially. The independent variables include personal factors (gender, age, marital status and family status), educational factors (school completion levels, undergraduate and post graduate qualifications attained), immigration factors (country of birth, year of arrival and language spoken at home), broad occupational groups (Managers; Professionals; Technicians; Community Workers; Clerks; Sales Persons; Labourers and others) and factors related to the sector of employment (government/non-government).

Having estimated the impact of the independent variables on hourly wage rate and weekly income, we then utilised the data to decompose the mean outcome differences between men and women within a region into that part that is 'explained' by gender differences in endowments and that part which remains unexplained by such differences 
and which therefore provides a measure of discrimination. Blinder-Oaxaca decomposition analysis is used to identify the level of discrimination.

NSW and Victoria are the two largest states in Australia in terms of population - together accounting for more than 58 percent of the country's population in 2006 (33\% in NSW and $25 \%$ in Victoria). Sydney metropolitan city is the state capital of NSW, and the largest metropolitan city in Australia with a population of about 4.1 million in 2006. Within NSW, SYD accounted for about 63 percent of the state population. The basic demographic features of the SYD labour market are quite different from the rest of the state. For example, the proportion of overseas born population in SYD was about 40 per cent compared with about 16.4 per cent for RNSW and about 29 per cent for Australia as a whole. Melbourne metropolitan city is the state capital of Victoria and accounts for about 72.8 per cent of the state population. The proportion of overseas born population in MELB (35.5 per cent) was also considerably higher than for the rest of RVIC (15.9 per cent). The Gender distribution of the population was very similar in each of the four regions - about 1,030 women per thousand men in SYD and RNSW; and about 1,040 women per thousand men in MELB and RVIC. (ABS, Online) ${ }^{1}$

Section 2 of this paper provides a brief account of the Australian labour market features based on a review of past literature. Section 3 describes the data and the method used in the analysis. Section 4 reports and analyses the quantitative results and section 5 concludes by summarising the findings and highlighting the implications of this research.

\section{The Australian Labour Market Features}

The Australian labour market is dominated by Australia's metropolitan cities. In general, personal factors such as gender, age and marital status have been commonly observed as factors that influence labour market outcomes in different countries and in diversified contexts (Edin 1989; Bradley and Taylor 1991; Narendranathan and Stewart 1993; Lazaro et al. 2000). The nature and composition of metropolitan and regional labour markets are also different and can be expected to provide for a wide range of outcomes.

Gender discrimination issues in labour markets have been highlighted in a range of studies, however, rarely is the issue dealt with in the context of locational differences. Some studies have tested the influence of gender as one of a number of factors influencing labour market outcomes across regions. For example, Mallik et al. (2014) observed that gender discrimination patterns were similar in Sydney and regional NSW labour markets in Australia (where men enjoyed a clear advantage). They also found that

\footnotetext{
${ }^{1} 2006$ Census data is used here to explain the features of the regions as the study used CURF data of the 2006 Census. The Basic demographic features of the two states have not changed noticeably in the more recent 2011 census. As per the 2011 Census, NSW and Victoria together accounted for about $57.1 \%$ of the Australian population (32.2\% in NSW and $24.9 \%$ in Victoria). In general, the demographic features of the two states and the metropolitan cities did not change significantly during the period 2006 and 2011.
} 
the metropolitan Sydney market places a greater value on higher education qualifications than do labour markets in regional NSW; and immigrants, particularly from non-English speaking countries, are more likely to be disadvantaged in Sydney.

Gender issues have frequently been highlighted in the many analyses of urban Australian labour markets (Li and Miller, 2012; Watson, 2010). It has been noted that women's participation in the labour force has been rising at a faster rate than that of men since the 1950 s as a result of changes in the structure of the society. At the same time researchers have become increasingly aware that urban women are confronted by gender-based discrimination. For example, a NSW government report (WRC, 2010), argued that women in NSW are paid less than men by about 18 per cent, have a higher proportion of parttime employment, and have lower levels of superannuation coverage. It has also been established that the gender pay gap is quite modest among 15-19 year olds, and increases with age (ABS, 2004).

Watson (2010) observed that women managers in Australia are significantly disadvantaged compared to men. Although their respective characteristics were very similar, earnings of men and women managers were very different which suggested clear discrimination. Using a Blinder-Oaxaca decomposition of the men/women pay gap among full-time managers in Australia over the period 2001 to 2008, the study found that "female managers earned on average about 27 per cent less than their male counterparts and the decompositions suggest that somewhere between 65 and 90 per cent of this earnings gap cannot be explained by recourse to a large range of demographic and labour market variables. A major part of the earnings gap is simply due to women managers being female" (pp. 53). Li and Miller (2012) examined gender differences and educational mismatch in the Australian graduate labour market using data from the Graduate Destination Surveys 1999-2009. With the help of Blinder-Oaxaca decomposition analysis they observed that there is gender discrimination in the form of a wage gap in the Australian graduate labour market, but the level of discrimination is modest. A smaller gender wage gap was found for university graduates than for all workers. However, the gender wage gap widens with the age at graduation. Findings of this study suggest that education may act as a tool for eliminating discrimination in the labour market. In their opinion, "as females are less overeducated than males, despite the larger representation of the former in higher education, there should not be concern that expanding higher education will disadvantage females" (pp. 195).

While addressing the question on how metropolitan area conditions impact ethnic labour force entrepreneurial choices across ethnicity and gender, within the contexts of different types of immigration gateways in the US, Wang (2010) observed that women were less likely to be self-employed than men, across all ethnic groups. The trend was more prominent for Afro-Americans and Asians. Asian women are less likely to be selfemployed in more established immigration gateways, which reduce their already lower rate of business ownership when compared with Asian men. In contrast, living in historic 
and more established gateways significantly increases the chances of self-employment for black women compared with other ethnic gender women. In his earlier research, Wang (2008) found that macroeconomic structure and racial composition had significant impacts on gender earnings disparities in the US. The directions and magnitudes of disparities were different among different racial groups. All racial and gender groups would benefit from more evenly distributed labour market among ethnic minorities and immigrants. This study also found higher earning gaps between different racial groups than between men and women. Also, women labourers were found to be more sensitive to macroeconomic conditions, racial residential segregation and labour market segmentation.

Lovell (2000) investigated the relationship between unequal regional development and racial and gender wage inequality in Brazil. The study observed that while women and Afro-Brazilians in Brazil's most developed region of São Paulo had the advantages of higher levels of state sponsored work benefits and more equitable occupational and wage distribution, they nevertheless experienced the greatest discrimination. In contrast, in the less developed state of Bahia, where racial and gender gaps in education, occupation and wages were the most severe, wage discrimination was lowest. Joachim and Alisher (2007) tested the variation of gender-specific labour-market participation rates across regions, and observed that a higher regional wage level fosters participation, whereas higher unemployment discourages workers.

Asplund and Napari (2011) compared the gender wage differentials of two occupation groups-innovation and non-innovation workers-separately for manufacturing and service industries using Finnish private-sector data for the period 2002-09. The study found conspicuous differences in average gender wage gaps in gender wage-gap profiles across the wage distribution and also in the evolution of gender wage differentials over time between sectors and occupation groups. Sector-specific factors appeared to be a more important driving force behind these differences in patterns and trends of gender wage gaps, although occupation-specific factors cannot be totally dismissed.

Although in a different socio-economic context, using the rural and urban labour market data from Bangladesh, Ahmed and Maitra (2010) found that gender wage differentials were considerably larger in urban areas than in rural areas and that a significant portion of this wage differential could be attributed to discrimination against women.

Syed and Murray (2009) analysed the labour market issues and challenges that migrant women from non-English speaking backgrounds faced in Australia from a human resource management perspective. Their findings indicate that the English language deficit and other structural challenges that these women face are generated in many contexts other than just the organisation. They argued that diversity cannot be realistically understood and managed unless issues of equal opportunity and intersectionality are tackled at multiple levels within and outside the workplace. Liu and Noback (2011) 
analysed the determinants of women labour participation using structural equation modelling with a dataset of 278 municipalities in the Netherlands. Their study found that the labour force participation of women is positively impacted by socio-economic status.

Turning to regional labour market differences, studies focussing on regional differences in labour market characteristics and outcomes abound. However, few of these studies analysed how these differences were impacted by gender. Several studies have focused on the urban-regional dichotomy of the labour market and noted, for example, that regional differences in participation and unemployment rates persist and that urban labour markets are growing both in size and diversity at faster rates than regional labour markets. (Dixon and Shepherd, 2011; Cunningham and Davis, 2011) Using multi-level survey and census data for Australian non-metropolitan regions Baum et al. (2008) observed that the risk of labour underutilisation in non-metropolitan regions was associated with a range of individual characteristics and circumstances together with the characteristics of the local labour market. Thus, policy designed to address issues of labour underutilisation needs to focus on both supply and demand-sides of the labour market in order to be effective. Howard (2005) however, argued in favour of broader policy approaches that reflect the needs of the times rather than regional needs. He attempted to identify the consistency in regional performances in Australia using a simple model with 25 years of labour market data from 1976 to 2001. The research showed evidence of consistency in performance across the regions after adjusting for ambiguities in the traditional measures of unemployment rates and participation rates.

Dixon and Shepherd (2011) analysed state and territory employment and unemployment patterns in Australia and recognized that the national indicators of macroeconomic performance might conceal differences at the local level which can cause regional economic disparities. Cunningham and Davis (2011) argued that, while labour market outcomes in regional Australia had followed broadly similar trends to those in capital cities in the last two decades, there are some notable differences - generally arsing as a result of industry location patterns. For example, analysis of the data showed regions dominated by mining activities had low unemployment rates; tourism and manufacturingbased regions had above average unemployment rates; and regions dominated by agricultural activities experienced rates close to the national average.

Using the British Household Panel Survey data for 1991-98, Gilbert et al. (2003, pp. 1218) observed that "urban wages are significantly higher than remote rural wages, even after adjustments were made for differences in characteristics such as education and industrial structure". They also found that lower wages are more predominant in remote rural areas as compared to accessible rural areas.

Thus, researchers have clearly observed that women workers are discriminated against in comparison to their male counterparts under different contexts. Women are less likely to be self-employed - a factor contributing to lower incomes than men. They are also 
likely to be discriminated against in employment through both the lower payment and lower employability for equivalent qualifications (compared with men). The literature also confirms the prevalence of geographic differences in employment outcomes - regions are often discriminated against large cities. A few studies on Australia also confirmed the two broad groups of outcomes. However, no research has attempted to combine gender and location issues together in the context of the labour market. This study intends to analyse the factors that influences specific outcomes in terms of differing wage and income experiences between men and women in metropolitan and regional areas in Australia. In particular we seek to establish if levels of discrimination against women varies between metropolitan and regional Australia.

\section{Data and Methodology}

The conceptual framework used in this research is in the tradition of human capital analysis (Mincer, 1974). It is argued that individual labour market outcomes with respect to earnings returns (hourly wage rate and weekly income) are a function of personal factors, educational factors, immigration factors and employment sector factors. As gender is to be used as the basic distinguishing factor in the analysis, each relationship is tested for men and women separately. A combined gender (persons) analysis is provided for comparison.

The primary econometric model used in this research is given by:

$$
Y=\alpha+X^{\prime} \beta+\varepsilon----------(1)
$$

where, the dependent variable $Y$ represents one of two earnings indicators - weekly income (InIncome) and hourly wage rate (InWage) to the set of explanatory variables included in vector $X$. These explanatory variables include: i. personal factors (gender, age, marital status and family status); ii. educational factors (school completion levels, undergraduate and post graduate qualifications attained); iii. immigration factors (country of birth, year of arrival and language spoken at home); iv. broad occupational groups (Managers; Professionals; Technicians; Community Workers; Clerks; Sales Persons; Labourers and others); and $v$. factors related to the sector of employment (government/non-government) respectively. $\varepsilon$ is the random error term. Thus, the primary equation generates two sets of results for two dependent variables. In keeping with the traditional derivation of earnings functions, both hourly wage rate and weekly income are expressed in the natural logarithmic form. To focus on gender issues, each equation is applied to three sets of data - men, women and combined persons. The variable 'gender' is used in the combined equations only and tests the significance of gender as an explanatory factor. To capture variations between states and regions, separate data sets on two Australian states (NSW and Victoria) and regions within the states (metropolitan area and the rest of the state) are used. Detailed descriptions of the 
variables and summary statistics of all dependent and independent variables are presented in Table 1.

Table 1: Summary statistics and the definition of the variables under study

\begin{tabular}{|c|c|c|c|c|c|c|c|c|}
\hline & \multicolumn{2}{|c|}{ Sydney } & \multicolumn{2}{|c|}{ RNSW } & \multicolumn{2}{|c|}{ Melbourne } & \multicolumn{2}{|l|}{ RVIC } \\
\hline & $\begin{array}{l}\text { Mea } \\
\mathrm{n}\end{array}$ & $\begin{array}{l}\text { Stde } \\
v\end{array}$ & $\begin{array}{l}\text { Mea } \\
\mathrm{n}\end{array}$ & $\begin{array}{l}\text { Stde } \\
\mathrm{v}\end{array}$ & $\begin{array}{l}\text { Mea } \\
\mathrm{n}\end{array}$ & $\begin{array}{l}\text { Stde } \\
\mathrm{v}\end{array}$ & $\begin{array}{l}\text { Mea } \\
\mathrm{n}\end{array}$ & $\begin{array}{l}\text { Stde } \\
\mathrm{v}\end{array}$ \\
\hline $\begin{array}{l}\text { INCOME=Actual income of the } \\
\text { individual (in AUD) per week }\end{array}$ & $\begin{array}{l}951 . \\
7\end{array}$ & $\begin{array}{l}647 . \\
0\end{array}$ & $\begin{array}{l}756 . \\
5\end{array}$ & $\begin{array}{l}533 . \\
5\end{array}$ & $\begin{array}{l}860 \\
9\end{array}$ & $\begin{array}{l}598 . \\
1\end{array}$ & $\begin{array}{l}731 . \\
9\end{array}$ & $\begin{array}{l}501 . \\
9\end{array}$ \\
\hline $\begin{array}{l}\text { WAGE=income/no of hours } \\
\text { worked during the week (in } \\
\text { AUD) }\end{array}$ & $\begin{array}{l}28.2 \\
3\end{array}$ & $\begin{array}{l}20.3 \\
5\end{array}$ & $\begin{array}{l}25.3 \\
9\end{array}$ & $\begin{array}{l}21.9 \\
1\end{array}$ & $\begin{array}{l}26.1 \\
8\end{array}$ & $\begin{array}{l}18.8 \\
7\end{array}$ & $\begin{array}{l}24.4 \\
8\end{array}$ & $\begin{array}{l}23.2 \\
8\end{array}$ \\
\hline $\begin{array}{l}\text { Dpg=Post graduate }(P G) \\
\text { degree; } P G \text { degree }=1 \text {, } \\
\text { otherwise }=0\end{array}$ & 0.06 & 0.24 & 0.02 & 0.15 & 0.05 & 0.21 & 0.02 & 0.12 \\
\hline $\begin{array}{l}\text { Dgdip }=\text { Graduate diploma; } \\
\text { graduate diploma }=1 \text {, } \\
\text { otherwise }=0\end{array}$ & 0.02 & 0.13 & 0.02 & 0.13 & 0.03 & 0.17 & 0.02 & 0.15 \\
\hline $\begin{array}{l}\text { Dbachelor=Bachelor's degree; } \\
\text { bachelor degree }=1 \text {, } \\
\text { otherwise }=0\end{array}$ & 0.21 & 0.41 & 0.11 & 0.32 & 0.20 & 0.40 & 0.11 & 0.32 \\
\hline $\begin{array}{l}\text { Dadvdip=Advance diploma } \\
\text { degree; advance diplomar }=1 \text {, } \\
\text { otherwise }=0\end{array}$ & 0.11 & 0.31 & 0.08 & 0.28 & 0.10 & 0.29 & 0.08 & 0.27 \\
\hline $\begin{array}{l}\text { Dcerti }=\text { Certificate; certificate }=1 \text {, } \\
\text { otherwise }=0\end{array}$ & 0.18 & 0.39 & 0.27 & 0.44 & 0.18 & 0.38 & 0.26 & 0.44 \\
\hline $\begin{array}{l}\text { Dhsc=Higher School Certificate } \\
\text { (HSC); HSC }=1 \text {, otherwise }=0\end{array}$ & 0.02 & 0.12 & 0.02 & 0.13 & 0.02 & 0.13 & 0.02 & 0.12 \\
\hline $\begin{array}{l}\text { Dteneleven=Above year } 10 \text { and } \\
\text { below HSC education; } \\
\text { completed year ten and below } \\
\text { HSC }=1 \text {, otherwise }=0\end{array}$ & 0.17 & 0.37 & 0.28 & 0.45 & 0.14 & 0.34 & 0.22 & 0.42 \\
\hline $\begin{array}{l}\text { Dbelowten=Below year } 10 \\
\text { education; below year ten=1; } \\
\text { otherwise=0 (default dummy) }\end{array}$ & 0.23 & 0.42 & 0.19 & 0.40 & 0.29 & 0.46 & 0.28 & 0.45 \\
\hline Age $=$ Age of the person in years & $\begin{array}{l}38.8 \\
2\end{array}$ & $\begin{array}{l}13.2 \\
5\end{array}$ & $\begin{array}{l}40.1 \\
0\end{array}$ & $\begin{array}{l}13.7 \\
6\end{array}$ & $\begin{array}{l}38.7 \\
6\end{array}$ & $\begin{array}{l}13.3 \\
5\end{array}$ & $\begin{array}{l}40.6 \\
7\end{array}$ & $\begin{array}{l}13.8 \\
8\end{array}$ \\
\hline $\begin{array}{l}\text { Baus=Born in Australia }=1 \\
\text { otherwise }=0\end{array}$ & 0.60 & 0.49 & 0.88 & 0.32 & 0.68 & 0.47 & 0.89 & 0.31 \\
\hline $\begin{array}{l}\text { Buknz=Born in UK and New } \\
\text { Zealand }=1 \text {, otherwise }=0\end{array}$ & 0.08 & 0.28 & 0.06 & 0.24 & 0.07 & 0.26 & 0.06 & 0.23 \\
\hline $\begin{array}{l}\text { Bchina=Born in China }=1 \text {, } \\
\text { otherwise }=0\end{array}$ & 0.03 & 0.18 & 0.00 & 0.04 & 0.02 & 0.13 & $\begin{array}{l}0.00 \\
1\end{array}$ & 0.04 \\
\hline $\begin{array}{l}\text { Basia=Born in India and South } \\
\text { east asia }=1 \text {; otherwise }=0\end{array}$ & 0.09 & 0.28 & 0.01 & 0.09 & 0.05 & 0.22 & 0.01 & 0.07 \\
\hline $\begin{array}{l}\text { Beurope }=\text { Born in Europe }=1 \\
\text { Otherwise }=0\end{array}$ & 0.07 & 0.25 & 0.03 & 0.16 & 0.03 & 0.16 & 0.01 & 0.10 \\
\hline Gender: Men $=1 ;$ Women $=0$ & 0.54 & 0.50 & 0.54 & 0.50 & 0.53 & 0.50 & 0.56 & 0.50 \\
\hline $\begin{array}{l}\text { LANP }=\text { Language spoken at } \\
\text { home; english }=1 \text {, otherwise }=0\end{array}$ & 0.69 & 0.46 & 0.96 & 0.20 & 0.75 & 0.43 & 0.95 & 0.21 \\
\hline MSTP=Marital Status, & 0.52 & 0.50 & 0.52 & 0.50 & 0.51 & 0.50 & 0.55 & 0.50 \\
\hline
\end{tabular}




\begin{tabular}{|c|c|c|c|c|c|c|c|c|}
\hline married $=1 ;$ otherwise $=0$ & & & & & & & & \\
\hline $\begin{array}{l}\text { YARP }=\text { Year of arrival in } \\
\text { Australia, arrived before } 1996=1 \text {, } \\
\text { during } 1996-99=2 \text {, during } 2000- \\
01 \text {, otherwise }=4\end{array}$ & 3.38 & 0.92 & 3.84 & 0.50 & 3.52 & 0.84 & 3.84 & 0.52 \\
\hline $\begin{array}{l}\text { Dfamily }=A \text { family person }=1 \text {; } \\
\text { otherwise }=0\end{array}$ & & & & & & & & \\
\hline $\begin{array}{l}\text { GOVT }=\text { Working in a } \\
\text { Government organisation }=1 \text {, } \\
\text { Otherwise }=0\end{array}$ & 0.12 & 0.32 & 0.14 & 0.35 & 0.12 & 0.32 & 0.14 & 0.35 \\
\hline $\begin{array}{l}\text { Dmanager }=\text { Occupation as a } \\
\text { manager }=1 ; \text { otherwise }=0\end{array}$ & & & & & & & & \\
\hline $\begin{array}{l}\text { Dprof }=\text { Occupation as a } \\
\text { profetional }=1 ; \text { otherwise }=0\end{array}$ & & & & & & & & \\
\hline $\begin{array}{l}\text { Dtech }=\text { Occupation as a } \\
\text { technician }=1 ; \text { otherwise }=0\end{array}$ & & & & & & & & \\
\hline $\begin{array}{l}\text { Dcomunity=Occupation as a } \\
\text { community worker }=1 ; \\
\text { otherwise }=0\end{array}$ & & & & & & & & \\
\hline $\begin{array}{l}\text { Dclarical=Occupation as a } \\
\text { clark }=1 ; \text { otherwise }=0\end{array}$ & & & & & & & & \\
\hline $\begin{array}{l}\text { Dsales }=\text { Occupation as a sales } \\
\text { person }=1 ; \text { otherwise }=0\end{array}$ & & & & & & & & \\
\hline $\begin{array}{l}\text { Dlabourr }=\text { Occupation as a } \\
\text { labourer }=1 ; \text { otherwise }=0\end{array}$ & & & & & & & & \\
\hline $\begin{array}{l}\text { Dsydney/Dmelbourne=Sydney/ } \\
\text { Melbourne=1; otherwise }=0\end{array}$ & & & & & & & & \\
\hline
\end{tabular}

The existing literature suggests that age should have a nonlinear relationship with employment outcomes (Gasteen and Houston, 2007; Florit and Lladosa, 2007). To test this hypothesis in the Australian context, this research has included age (Age) and agesquared $\left(\mathrm{Age}^{2 / 100)}\right.$ as independent variables in equation (1). If the hypothesised relationship is supported by the data, the estimated coefficient of age, should be positive, and the estimated coefficient for $\mathrm{Age}^{2}$ divided by 100 , should be negative. The threshold age is calculated by differentiating equation (1) with respect to age and equating the same with zero.

Ordinary least squares (OLS) method is used as the estimation procedure for both sets of relationships here as the dependent variables are the natural logarithm of monetary values. However, it is possible that when equation (1) (in case of 'InWage') is estimated from self-selected samples, the estimated parameters may be biased and inconsistent. In order to obtain consistent estimates of the parameters James Heckman (1979) introduced an estimation procedure utilising maximum likelihood methods. This paper has used both Ordinary Least Squares (OLS) and the Heckman selection model for the wage equations. However, only the Heckman selection model results are presented.

To analyse the mean outcome differences in wage and income gaps between men and women we have utilised the Blinder-Oaxaca decomposition (Jann, 2008) which divides the differential into a part that is explained by differences in endowments (education, age 
etc), a part that measures the contribution of differences in the coefficients (which is unexplained by endowments and, as such, becomes our measure of discrimination) and an interaction term which recognises that differences in endowments and coefficients can simultaneously exist. Usually, a major issue in the use of the Blinder-Oaxaca decomposition is the choice of non-discriminatory wage structure. One can, for example, assume that the wage structure for men is non-discriminatory and that women are disadvantaged. This is the most common approach. Alternatives would be to assume that the women wage structure is the non-discriminatory structure (and that men are advantaged) or to use a pooled wage structure which could then be used to assess both the disadvantages of being female and the advantages of being male. Our concern, however, is to assess if the treatment of men and women differ between metropolitan labour markets and regional labour markets which makes the choice of nondiscriminatory wage structure less problematic.

The research used individual level micro data from the 2006 Census Sample File (CSF) available through confidentialised unit record files (CURF) released by the ABS for a range of regions (ABS, 2006). CSF is a sample of occupied private dwellings, with their associated family and personal records. A sample of one percent basic census sample file is available through CURF. The CURF has been designed in such a way that the information on the file is not likely to enable the identification of the particular person to which it relates.

This research compared performances of men and women in the labour force in metropolitan cities and in regional areas in the two largest states in Australia in terms of population, New South Wales (NSW) and Victoria (VIC). Sydney (SYD) and Melbourne (MELB) metropolitan areas are defined as per the ABS definition of the respective Statistical Divisions for Sydney and Melbourne. RNSW is defined as the state of New South Wales (NSW) excluding the Sydney Statistical Division and RVIC is defined as the state of Victoria excluding the Melbourne Statistical Division.

For this analysis data for individuals aged between 17 and 70 have been used. After extensive cleaning of the data (to remove observations where data on all variables was unavailable) a number of useable datasets were identified. For NSW, a dataset of 27,135 individuals $(16,291$ for SYD and 10,844 for RNSW) is used in income relationships (55.6\% men); and 28,437 individuals (17,370 for SYD and 11,067 for RNSW) in wage relationships $(54.3 \%$ men). Similarly, for Victoria, datasets of 21,412 individuals $(16,024$ for MELB and 5,388 for RVIC) and 21,932 individuals (16,417 for MELB and 5,515 for $\mathrm{RVIC}$ ) are used in income and wage relationships respectively (53.8\% are men in both). Sample sizes for individual equations are provided with the analysis of results.

Analysis of raw data suggested that, in general, average hourly wage rates and average weekly incomes were higher for SYD and RNSW than for MELB and RVIC respectively. Moreover, average hourly wage rates and average weekly incomes were higher in 
metropolitan cities (SYD and MELB) than in their respective regional areas (RNSW and RVIC). Regional areas in both states (RNSW and RVIC) had a higher average age of workers, possibly due to the dominance of agriculture and family businesses in the regions. As expected, the proportion of immigrants in SYD was higher than MELB (about 35.5 in MELB as compared to $40 \%$ in SYD) - resulting in a greater diversity of languages and culture. Regional areas in both states had lower proportions of overseas born population and were similar in terms of diversity. SYD and MELB had higher proportions of bachelor and post-graduate degree holders in the labour market; whereas RNSW and RVIC had more certificate holders.

Raw data also reveals that hourly wage rates were similar between genders mainly due to Australia's non-discriminatory wage determination policies. Exceptions were found among workers in RVIC for two particular educational qualification groups - 'HSC' and 'below year twelve', where the wage rates for women were marginally higher than for men. This was possibly due to a higher proportion of boys moving to metropolitan areas to continue their education. Weekly incomes earned by women were consistently lower than men in all areas possibly due to a higher proportion of part-time workers among women. Income differences were higher in SYD than MELB whereas regional areas in both states were similar. However, across all regions, income differences were lower for the more highly educated groups.

\section{Results and Discussion}

Estimated coefficient values and the respective p-values of the primary equation for weekly income (InIncome) for SYD and RNSW are presented in Table 2; and for MELB and RVIC in Table 3. Estimated results of the equation for hourly wage rates (InWage) for SYD and RNSW are presented in Table 4; and for MELB and RVIC in Table 5. Estimates from the Blinder-Oaxaca decomposition model are in Table 6.

As the results indicate (Tables 2, 3, 4 and 5), coefficients for gender were found to be positive and highly significant in all combined relationships except in the case of RVIC for wage. This indicates discrimination against women which is further explored with BlinderOaxaca deposition below. RVIC has the smallest sample in this analysis and covers a relatively small geographical area.

As Tables 2 and 3 indicate, higher education contributed to higher income for both genders in all regions. For each gender, workers with lower qualifications consistently experienced wage disadvantages in all regions. Being married clearly acted as a disadvantage for women workers in Melbourne and in regional Victoria. For Sydney and regional NSW, although the sign of the coefficients for women are negative, they are not found to be significant. Having a family acted as a positive factor for both genders in all markets. Employees with families earned higher income, possibly due to greater domestic responsibilities. 
Table 2: Estimated coefficients of labour market outcome - Income - Sydney and Other NSW

\begin{tabular}{|c|c|c|c|c|c|c|c|}
\hline & \multicolumn{7}{|c|}{ Dependent variable: Lnlncome } \\
\hline & \multicolumn{3}{|c|}{ Sydney (SYD) } & \multicolumn{3}{|c|}{ Other NSW (RNSW) } & \multirow{2}{*}{$\begin{array}{l}\text { Sydney } \\
\text { and other } \\
\text { NSW }\end{array}$} \\
\hline & Men & Women & All & Men & Women & All & \\
\hline Dpg & $\begin{array}{l}0.315^{\star * *} \\
(10.66)\end{array}$ & $\begin{array}{l}0.426^{\star * *} \\
(12.24)\end{array}$ & $\begin{array}{l}0.373^{\star * *} \\
(16.39)\end{array}$ & $\begin{array}{l}0.468^{\star \star \star} \\
(7.78)\end{array}$ & $\begin{array}{l}0.498^{\star \star \star} \\
(6.95)\end{array}$ & $\begin{array}{l}0.485^{\star * *} \\
(10.48)\end{array}$ & $\begin{array}{l}0.414^{\star * *} \\
(20.15)\end{array}$ \\
\hline Dgradip & $\begin{array}{l}0.153^{\star * *} \\
(2.68)\end{array}$ & $\begin{array}{l}0.293^{\star * *} \\
(6.11)\end{array}$ & $\begin{array}{l}0.233^{\star * *} \\
(6.33)\end{array}$ & $\begin{array}{l}0.271^{* \star *} \\
(3.44)\end{array}$ & $\begin{array}{l}0.350^{\star * \star} \\
(5.39)\end{array}$ & $\begin{array}{l}0.328^{\star \star *} \\
(6.51)\end{array}$ & $\begin{array}{l}0.274^{* * *} \\
(9.18)\end{array}$ \\
\hline Dbachelor & $\begin{array}{l}0.304^{* * *} \\
(14.56)\end{array}$ & $\begin{array}{l}0.282^{* \star *} \\
(12.15)\end{array}$ & $\begin{array}{l}0.303^{\star \star \star} \\
(19.33)\end{array}$ & $\begin{array}{l}0.416^{\star \star \star} \\
(11.23)\end{array}$ & $\begin{array}{l}0.326^{\star * \star} \\
(9.06)\end{array}$ & $\begin{array}{l}0.365^{\star \star *} \\
(14.05)\end{array}$ & $\begin{array}{l}0.326^{\star * *} \\
(24.13)\end{array}$ \\
\hline Dadvdip & $\begin{array}{l}0.178^{\star \star \star} \\
(7.16)\end{array}$ & $\begin{array}{l}0.128^{\star \star \star} \\
(4.99)\end{array}$ & $\begin{array}{l}0.154^{\star \star \star} \\
(8.56)\end{array}$ & $\begin{array}{l}0.282^{\star \star \star} \\
(7.46)\end{array}$ & $\begin{array}{l}0.188^{* \star *} \\
(5.22)\end{array}$ & $\begin{array}{l}0.232^{\star \star \star} \\
(8.84)\end{array}$ & $\begin{array}{l}0.183 \\
(12.23)\end{array}$ \\
\hline Dcer & $\begin{array}{l}0.093^{* * *} \\
(4.75)\end{array}$ & $\begin{array}{l}0.060^{\star \star} \\
(2.34)\end{array}$ & $\begin{array}{l}0.094^{* * *} \\
(6.04)\end{array}$ & $\begin{array}{l}0.135^{\star * *} \\
(5.26)\end{array}$ & $\begin{array}{l}0.073^{\star *} \\
(2.51)\end{array}$ & $\begin{array}{l}0.117^{* * *} \\
(6.04)\end{array}$ & $\begin{array}{l}0.100^{\star * *} \\
(8.26)\end{array}$ \\
\hline Dtwelve & $\begin{array}{l}-0.058 \\
(-1.08) \\
\end{array}$ & $\begin{array}{l}-0.023 \\
(-0.37)\end{array}$ & $\begin{array}{l}-0.040 \\
(-0.97)\end{array}$ & $\begin{array}{l}-0.088 \\
(-1.28) \\
\end{array}$ & $\begin{array}{l}-0.024 \\
(-0.33)\end{array}$ & $\begin{array}{l}-0.061 \\
(-1.19) \\
\end{array}$ & $\begin{array}{l}-0.052 \\
(-1.60) \\
\end{array}$ \\
\hline Deleven & $\begin{array}{l}-0.085^{* * *} \\
(-3.99)\end{array}$ & $\begin{array}{l}-0.123^{* * \star} \\
(-5.19)\end{array}$ & $\begin{array}{l}-0.117^{* * \star} \\
(-7.29)\end{array}$ & $\begin{array}{l}-0.042 \\
(-1.60)\end{array}$ & $\begin{array}{l}0.071^{* * *} \\
(-2.61)\end{array}$ & $\begin{array}{l}-0.062^{* * *} \\
(-3.25)\end{array}$ & $\begin{array}{l}-0.095^{* * *} \\
(-7.80)\end{array}$ \\
\hline Age & $\begin{array}{l}0.087^{* * *} \\
(29.70)\end{array}$ & $\begin{array}{l}0.085^{\star * *} \\
(23.22)\end{array}$ & $\begin{array}{l}0.085^{\star * *} \\
(37.13)\end{array}$ & $\begin{array}{l}0.079^{\star \star *} \\
(22.37) \\
\end{array}$ & $\begin{array}{l}0.079^{\star \star \star} \\
(19.35) \\
\end{array}$ & $\begin{array}{l}0.080^{\star \star *} \\
(29.87)\end{array}$ & $\begin{array}{l}0.083^{* * *} \\
(47.73)\end{array}$ \\
\hline Agesq & $\begin{array}{l}-0.092^{* * *} \\
(-27.00)\end{array}$ & $\begin{array}{l}-0.091^{* * *} \\
(-20.74)\end{array}$ & $\begin{array}{l}-0.090^{\star * *} \\
(-33.28)\end{array}$ & $\begin{array}{l}-0.087^{\star * *} \\
(-21.47)\end{array}$ & $\begin{array}{l}- \\
0.083^{\star * *} \\
(-16.89)\end{array}$ & $\begin{array}{l}-0.086^{\star * *} \\
(-27.40)\end{array}$ & $\begin{array}{l}-0.089^{\star \star \star} \\
(-43.31)\end{array}$ \\
\hline Baus & $\begin{array}{l}0.081^{* * *} \\
(2.97)\end{array}$ & $\begin{array}{l}-0.012 \\
(-0.38) \\
\end{array}$ & $\begin{array}{l}0.042^{* *} \\
(1.99)\end{array}$ & $\begin{array}{l}0.076 \\
(1.12) \\
\end{array}$ & $\begin{array}{l}-0.051 \\
(-0.69)\end{array}$ & $\begin{array}{l}0.017 \\
(0.34)\end{array}$ & $\begin{array}{l}0.032 \\
(1.63)\end{array}$ \\
\hline Buknz & $\begin{array}{l}0.148^{\star \star \star} \\
(5.33)\end{array}$ & $\begin{array}{l}0.006 \\
(0.16) \\
\end{array}$ & $\begin{array}{l}0.099^{\star \star \star} \\
(4.54)\end{array}$ & $\begin{array}{l}0.027 \\
(0.48) \\
\end{array}$ & $\begin{array}{l}0.056 \\
(0.91) \\
\end{array}$ & $\begin{array}{l}0.031 \\
(0.74) \\
\end{array}$ & $\begin{array}{l}0.079^{\star \star \star} \\
(4.13)\end{array}$ \\
\hline Bchina & $\begin{array}{l}-0.387^{* * *} \\
(-10.29)\end{array}$ & $\begin{array}{l}-0.253^{\star * *} \\
(-5.80)\end{array}$ & $\begin{array}{l}-0.322^{* * *} \\
(-11.17)\end{array}$ & $\begin{array}{l}-0.499^{* * *} \\
(-2.85)\end{array}$ & $\begin{array}{l}-0.166 \\
(-0.73)\end{array}$ & $\begin{array}{l}-0.384^{* * *} \\
(-2.75)\end{array}$ & $\begin{array}{l}-0.319^{* * *} \\
(-11.10)\end{array}$ \\
\hline Basia & $\begin{array}{l}-0.128^{* * *} \\
(-4.56)\end{array}$ & $\begin{array}{l}-0.033 \\
(-1.00)\end{array}$ & $\begin{array}{l}-0.082^{\star * *} \\
(-3.77)\end{array}$ & $\begin{array}{l}-0.150 \\
(-1.29)\end{array}$ & $\begin{array}{l}0.008 \\
(0.08)\end{array}$ & $\begin{array}{l}-0.091 \\
(-1.12)\end{array}$ & $\begin{array}{l}-0.089^{* * *} \\
(-4.17)\end{array}$ \\
\hline Beurope & $\begin{array}{l}0.058 \\
(1.29) \\
\end{array}$ & $\begin{array}{l}0.002 \\
(0.04)\end{array}$ & $\begin{array}{l}0.043 \\
(1.22) \\
\end{array}$ & $\begin{array}{l}0.102 \\
(1.02) \\
\end{array}$ & $\begin{array}{l}-0.033 \\
(-0.29) \\
\end{array}$ & $\begin{array}{l}0.036 \\
(0.48) \\
\end{array}$ & $\begin{array}{l}0.053 \\
(1.64) \\
\end{array}$ \\
\hline Genderp & & & $\begin{array}{l}0.287^{\star \star *} \\
(27.29)\end{array}$ & & & $\begin{array}{l}0.430^{\star \star \star} \\
(31.11)\end{array}$ & $\begin{array}{l}0.342^{\star \star \star} \\
(40.60)\end{array}$ \\
\hline Lanp & $\begin{array}{l}0.144^{* * *} \\
(7.71)\end{array}$ & $\begin{array}{l}0.059^{\star \star *} \\
(2.72)\end{array}$ & $\begin{array}{l}0.104^{* * *} \\
(7.28)\end{array}$ & $\begin{array}{l}0.032 \\
(0.68)\end{array}$ & $\begin{array}{l}-0.076 \\
(-1.46) \\
\end{array}$ & $\begin{array}{l}-0.009 \\
(-0.26)\end{array}$ & $\begin{array}{l}0.097^{\star * *} \\
(7.26)\end{array}$ \\
\hline Mstp & 0.009 & -0.221 & -0.100 & 0.090 & -0.207 & -0.049 & $\begin{array}{l}-0.080^{* * *} \\
(-6.70)\end{array}$ \\
\hline Varp & $\begin{array}{l}0.000 \\
(-0.01)\end{array}$ & $\begin{array}{l}-0.002 \\
(0.15) \\
\end{array}$ & $\begin{array}{l}-0.001 \\
(-0.10) \\
\end{array}$ & $\begin{array}{l}-0.039 \\
(-1.11) \\
\end{array}$ & $\begin{array}{l}0.110^{\star \star \star} \\
(2.80)\end{array}$ & $\begin{array}{l}0.024 \\
(0.93)\end{array}$ & $\begin{array}{l}0.007 \\
(0.74)\end{array}$ \\
\hline Dfamily & $\begin{array}{l}0.204^{* * *} \\
(9.94)\end{array}$ & $\begin{array}{l}0.121^{\text {***}} \\
(5.19)\end{array}$ & $\begin{array}{l}0.170^{\star \star \star} \\
(10.91)\end{array}$ & $\begin{array}{l}0.119^{\star \star \star} \\
(4.79)\end{array}$ & $\begin{array}{l}0.049^{*} \\
(1.78)\end{array}$ & $\begin{array}{l}0.086^{\star * *} \\
(4.61)\end{array}$ & $\begin{array}{l}0.137^{\star \star *} \\
(11.40)\end{array}$ \\
\hline Govt & $\begin{array}{l}0.123^{* * *} \\
(5.84)\end{array}$ & $\begin{array}{l}0.119^{* \star *} \\
(5.55)\end{array}$ & $\begin{array}{l}0.123^{\star * *} \\
(8.15)\end{array}$ & $\begin{array}{l}0.272^{\star * \star} \\
(10.19)\end{array}$ & $\begin{array}{l}0.267^{\star \star \star} \\
(10.37) \\
\end{array}$ & $\begin{array}{l}0.276^{\star * *} \\
(14.85)\end{array}$ & $\begin{array}{l}0.190^{\star * *} \\
(16.15)\end{array}$ \\
\hline Dmanager & $\begin{array}{l}0.607^{* * *} \\
(25.72)\end{array}$ & $\begin{array}{l}0.543^{* * *} \\
(10.76)\end{array}$ & $\begin{array}{l}0.654^{* * *} \\
(31.25)\end{array}$ & $\begin{array}{l}0.285^{\star * *} \\
(9.79)\end{array}$ & $\begin{array}{l}0.722^{\star \star *} \\
(15.91) \\
\end{array}$ & $\begin{array}{l}0.417^{\star * *} \\
(16.99)\end{array}$ & $\begin{array}{l}0.558 \\
(35.02) \\
\end{array}$ \\
\hline Dprof & $\begin{array}{l}0.590^{* * *} \\
(25.12)\end{array}$ & $\begin{array}{l}0.313^{\star * *} \\
(6.47)\end{array}$ & $\begin{array}{l}0.536^{\star * *} \\
(26.40)\end{array}$ & $\begin{array}{l}0.370^{\star \star \star} \\
(10.45)\end{array}$ & $\begin{array}{l}0.705^{\star \star \star} \\
(15.93)\end{array}$ & $\begin{array}{l}0.476^{\star * *} \\
(17.53)\end{array}$ & $\begin{array}{l}0.514^{\star * *} \\
(31.98)\end{array}$ \\
\hline Dtach & $0.267^{\star \star *}$ & 0.014 & $0.245^{\star \star \star}$ & $0.226^{\star \star \star}$ & $0.430^{\star \star *}$ & $0.285^{\star \star \star}$ & $0.267^{\star \star \star}$ \\
\hline
\end{tabular}




\begin{tabular}{|c|c|c|c|c|c|c|c|}
\hline & $(11.97)$ & $(0.25)$ & $(11.73)$ & $(8.41)$ & (8.06) & (11.98) & (16.93) \\
\hline Dcomper & $\begin{array}{l}0.092^{\star \star *} \\
(2.81)\end{array}$ & $\begin{array}{l}-0.186^{* * *} \\
(-3.72)\end{array}$ & $\begin{array}{l}0.025 \\
(1.03)\end{array}$ & $\begin{array}{l}0.091^{\star \star} \\
(2.11)\end{array}$ & $\begin{array}{l}0.333^{\star \star \star} \\
(8.07)\end{array}$ & $\begin{array}{l}0.143^{\star * *} \\
(5.24)\end{array}$ & $\begin{array}{l}0.072^{\star * *} \\
(4.00)\end{array}$ \\
\hline Dclarical & $\begin{array}{l}0.365^{\star * *} \\
(13.43)\end{array}$ & $\begin{array}{l}0.158^{\star * *} \\
(3.36)\end{array}$ & $\begin{array}{l}0.337^{* * *} \\
(16.49)\end{array}$ & $\begin{array}{l}0.226^{* * *} \\
(5.08)\end{array}$ & $\begin{array}{l}0.594^{\star \star \star} \\
(15.12)\end{array}$ & $\begin{array}{l}0.367^{* * *} \\
(14.26)\end{array}$ & $\begin{array}{l}0.345^{\star * *} \\
(21.64)\end{array}$ \\
\hline Dsales & $\begin{array}{l}0.101^{\star * *} \\
(3.51)\end{array}$ & $\begin{array}{l}-0.257^{* * *} \\
(-5.16)\end{array}$ & $\begin{array}{l}0.007 \\
(0.33)\end{array}$ & $\begin{array}{l}0.034 \\
(0.91)\end{array}$ & $\begin{array}{l}0.266^{\star * *} \\
(6.43)\end{array}$ & $\begin{array}{l}0.090^{\star * *} \\
(3.41)\end{array}$ & $\begin{array}{l}0.038^{* *} \\
(2.20)\end{array}$ \\
\hline Dlabour & $\begin{array}{l}-0.016 \\
(-0.62)\end{array}$ & $\begin{array}{l}-0.164^{* * *} \\
(-3.03)\end{array}$ & $\begin{array}{l}-0.023 \\
(-0.99) \\
\end{array}$ & $\begin{array}{l}-0.033 \\
(-1.10)\end{array}$ & $\begin{array}{l}0.190^{\star \star \star} \\
(4.17)\end{array}$ & $\begin{array}{l}0.014 \\
(0.56)\end{array}$ & $\begin{array}{l}-0.002 \\
(-0.14)\end{array}$ \\
\hline Dsydney & & & & & & & $\begin{array}{l}0.199^{\star * \star} \\
(23.67)\end{array}$ \\
\hline Constant & $\begin{array}{l}4.176^{\star * *} \\
(63.29)\end{array}$ & $\begin{array}{l}4.503^{\star * *} \\
(50.51)\end{array}$ & $\begin{array}{l}4.095^{\star * *} \\
(77.79)\end{array}$ & $\begin{array}{l}4.566^{* * *} \\
(38.66)\end{array}$ & $\begin{array}{l}3.671^{* * *} \\
(26.65)\end{array}$ & $\begin{array}{l}3.971^{* * *} \\
(43.82)\end{array}$ & $\begin{array}{l}3.900^{\star * *} \\
(89.90)\end{array}$ \\
\hline Adjusted $\mathrm{R}^{2}$ & 0.425 & 0.357 & 0.397 & 0.320 & 0.338 & 0.353 & 0.388 \\
\hline F-stat & $262.19^{\star \star \star}$ & $152.14^{\star \star \star}$ & $398.00^{* * *}$ & $108.03^{\star * *}$ & $98.07^{\star \star \star}$ & $219.88^{\star \star \star}$ & $615.60^{\star * \star}$ \\
\hline $\begin{array}{l}\text { No. of } \\
\text { Observations }\end{array}$ & 9,198 & 7,093 & 16,291 & 5,902 & 4,942 & 10,844 & 27135 \\
\hline Threshold Age & 47.50 & 46.39 & 47.16 & 45.25 & 47.59 & 46.48 & 46.85 \\
\hline
\end{tabular}

Figures in brackets indicate $p$-values.

${ }^{* * *},{ }^{* *},{ }^{*}$ indicates significant at $1 \%, 5 \%$ and $10 \%$ level respectively. 
Table 3: Estimated coefficients of labour market outcome - Income - Melbourne and Other Victoria

\begin{tabular}{|c|c|c|c|c|c|c|c|}
\hline & \multicolumn{7}{|c|}{ Dependent variable: LnIncome } \\
\hline & \multicolumn{3}{|c|}{ Melbourne (MELB) } & \multicolumn{3}{|c|}{ Other Victoria (RVIC) } & \multirow{2}{*}{$\begin{array}{l}\text { Melbourne } \\
\text { and other } \\
\text { Victoria }\end{array}$} \\
\hline & Men & Women & All & Men & Women & All & \\
\hline Dpg & $\begin{array}{l}0.372^{* * *} \\
(11.13)\end{array}$ & $\begin{array}{l}0.495^{\star \star \star} \\
(12.05)\end{array}$ & $\begin{array}{l}0.434^{* * *} \\
(16.52)\end{array}$ & $\begin{array}{l}0.517^{\star \star \star} \\
(5.01)\end{array}$ & $\begin{array}{l}0.495^{\star \star \star} \\
(4.54)\end{array}$ & $\begin{array}{l}0.531^{* * *} \\
(7.04)\end{array}$ & $\begin{array}{l}0.454^{* * *} \\
(18.37)\end{array}$ \\
\hline Dgradip & $\begin{array}{l}0.221^{* * *} \\
(4.62)\end{array}$ & $\begin{array}{l}0.342^{* * *} \\
(8.10)\end{array}$ & $\begin{array}{l}0.286^{* * *} \\
(9.07)\end{array}$ & $\begin{array}{l}0.188^{*} \\
(1.96)\end{array}$ & $\begin{array}{l}0.374^{\star * *} \\
(4.40)\end{array}$ & $\begin{array}{l}0.306^{* * *} \\
(4.79)\end{array}$ & $\begin{array}{l}0.293^{* * *} \\
(10.33)\end{array}$ \\
\hline Dbachelor & $\begin{array}{l}0.264^{\text {*** }} \\
(11.98)\end{array}$ & $\begin{array}{l}0.350^{\star * *} \\
(14.79)\end{array}$ & $\begin{array}{l}0.314^{\star * *} \\
(19.31)\end{array}$ & $\begin{array}{l}0.277^{\star * \star} \\
(5.43)\end{array}$ & $\begin{array}{l}0.337^{\star * *} \\
(6.66)\end{array}$ & $\begin{array}{l}0.317^{* *} \\
(8.78)\end{array}$ & $\begin{array}{l}0.317^{\star * *} \\
(21.42)\end{array}$ \\
\hline Dadvdip & $\begin{array}{l}0.161^{* * *} \\
(6.02)\end{array}$ & $\begin{array}{l}0.169^{\star \star *} \\
(6.43)\end{array}$ & $\begin{array}{l}0.169^{\star \star *} \\
(8.92)\end{array}$ & $\begin{array}{l}0.160^{\star * \star} \\
(3.05)\end{array}$ & $\begin{array}{l}0.051 \\
(1.01) \\
\end{array}$ & $\begin{array}{l}0.112^{* * *} \\
(3.06)\end{array}$ & $\begin{array}{l}0.154^{* * *} \\
(9.17)\end{array}$ \\
\hline Dcer & $\begin{array}{l}0.106^{* * *} \\
(5.34)\end{array}$ & $\begin{array}{l}0.106^{\star \star *} \\
(4.03)\end{array}$ & $\begin{array}{l}0.129^{\star * *} \\
(8.13)\end{array}$ & $\begin{array}{l}0.059^{*} \\
(1.83)\end{array}$ & $\begin{array}{l}0.132^{\star \star \star} \\
(3.34)\end{array}$ & $\begin{array}{l}0.096^{* * *} \\
(3.86)\end{array}$ & $\begin{array}{l}0.126^{\star * \star} \\
(9.37)\end{array}$ \\
\hline Dtwelve & $\begin{array}{l}-0.041 \\
(-0.80)\end{array}$ & $\begin{array}{l}0.099 \\
(1.64)\end{array}$ & $\begin{array}{l}0.025 \\
(0.62)\end{array}$ & $\begin{array}{l}-0.290^{* * *} \\
(-3.21)\end{array}$ & $\begin{array}{l}-0.039 \\
(-0.33)\end{array}$ & $\begin{array}{l}-0.179^{\star *} \\
(-2.47)\end{array}$ & $\begin{array}{l}-0.024 \\
(-0.68)\end{array}$ \\
\hline Deleven & $\begin{array}{l}-0.073^{\star \star \star} \\
(-3.19)\end{array}$ & $\begin{array}{l}-0.064^{\star \star} \\
(-2.57)\end{array}$ & $\begin{array}{l}-0.070^{\star \star \star} \\
(-4.12)\end{array}$ & $\begin{array}{l}-0.107^{\star \star \star} \\
(-3.09)\end{array}$ & $\begin{array}{l}-0.081^{\star *} \\
(-2.16)\end{array}$ & $\begin{array}{l}0.103^{* * *} \\
(-4.02)\end{array}$ & $\begin{array}{l}-0.080^{\star \star \star} \\
(-5.61)\end{array}$ \\
\hline Age & $\begin{array}{l}0.092^{* * *} \\
(30.10)\end{array}$ & \begin{tabular}{|l|}
$0.084^{\star \star *}$ \\
$(23.24)$ \\
\end{tabular} & $\begin{array}{l}0.088^{\star \star *} \\
(37.45)\end{array}$ & $\begin{array}{l}0.079^{\star \star \star} \\
(16.61)\end{array}$ & $\begin{array}{l}0.073^{\star \star \star} \\
(12.30)\end{array}$ & $\begin{array}{l}0.076^{* * *} \\
(20.59)\end{array}$ & $\begin{array}{l}0.086^{* * *} \\
(42.5)\end{array}$ \\
\hline Agesq & $\begin{array}{l}-0.097^{* * *} \\
(-27.35)\end{array}$ & $\begin{array}{l}-0.089^{\star * \star} \\
(-20.27)\end{array}$ & $\begin{array}{l}-0.092^{* * *} \\
(-33.21)\end{array}$ & $\begin{array}{l}-0.085^{\star * *} \\
(-16.84)\end{array}$ & $\begin{array}{l}0.077^{\star * *} \\
(-10.96)\end{array}$ & $\begin{array}{l}0.082^{* * *} \\
(-18.99)\end{array}$ & $\begin{array}{l}-0.091^{* * *} \\
(-39.13)\end{array}$ \\
\hline Baus & $\begin{array}{l}0.069^{\star \star} \\
(2.16)\end{array}$ & $\begin{array}{l}-0.064^{*} \\
(-1.73)\end{array}$ & $\begin{array}{l}-0.002 \\
(-1.10)\end{array}$ & $\begin{array}{l}0.136 \\
(1.48)\end{array}$ & $\begin{array}{l}-0.109 \\
(-0.95)\end{array}$ & $\begin{array}{l}0.015 \\
(0.22)\end{array}$ & $\begin{array}{l}-0.004 \\
(-0.18)\end{array}$ \\
\hline Buknz & $\begin{array}{l}0.145^{\star * *} \\
(4.45)\end{array}$ & $\begin{array}{l}0.035 \\
(0.91)\end{array}$ & $\begin{array}{l}0.094^{* * *} \\
(3.73)\end{array}$ & $\begin{array}{l}0.146^{*} \\
(1.84)\end{array}$ & $\begin{array}{l}-0.183^{*} \\
(-1.93)\end{array}$ & $\begin{array}{l}0.000 \\
(0.01)\end{array}$ & $\begin{array}{l}0.081^{* * *} \\
(3.50)\end{array}$ \\
\hline Bchina & $\begin{array}{l}-0.348^{\star * *} \\
(-6.08)\end{array}$ & $\begin{array}{l}-0.250^{* * *} \\
(-3.98) \\
\end{array}$ & $\begin{array}{l}-0.292^{\star \star *} \\
(-3.83)\end{array}$ & $\begin{array}{l}-0.239 \\
(-0.84) \\
\end{array}$ & $\begin{array}{l}-0.632 \\
(-1.37) \\
\end{array}$ & $\begin{array}{l}-0.365 \\
(-1.48) \\
\end{array}$ & $\begin{array}{l}-0.298^{\star \star \star} \\
(-7.08)\end{array}$ \\
\hline Basia & $\begin{array}{l}-0.101^{* * *} \\
(-3.04)\end{array}$ & $\begin{array}{l}-0.034 \\
(-0.87) \\
\end{array}$ & $\begin{array}{l}-0.070^{\star * *} \\
(-2.75)\end{array}$ & $\begin{array}{l}0.145 \\
(0.85) \\
\end{array}$ & $\begin{array}{l}-0.242 \\
(-1.20) \\
\end{array}$ & $\begin{array}{l}-0.062 \\
(-0.47) \\
\end{array}$ & $\begin{array}{l}-0.076^{* * *} \\
(-3.03)\end{array}$ \\
\hline Beurope & $\begin{array}{l}0.013 \\
(0.32)\end{array}$ & $\begin{array}{l}-0.030 \\
(-0.54)\end{array}$ & $\begin{array}{l}-0.002 \\
(-0.06)\end{array}$ & $\begin{array}{l}0.024 \\
(0.20)\end{array}$ & $\begin{array}{l}-0.342^{*} \\
(-1.92)\end{array}$ & $\begin{array}{l}-0.111 \\
(-1.11)\end{array}$ & $\begin{array}{l}-0.003 \\
(-0.09)\end{array}$ \\
\hline Genderp & & & $\begin{array}{l}0.370^{\star * *} \\
(33.65)\end{array}$ & & & $\begin{array}{l}0.429^{* * *} \\
(21.86)\end{array}$ & $\begin{array}{l}0.383^{* * *} \\
(39.83)\end{array}$ \\
\hline Lanp & $\begin{array}{l}0.062^{* * *} \\
(2.97)\end{array}$ & \begin{tabular}{|l|}
0.018 \\
$(0.78)$
\end{tabular} & $\begin{array}{l}0.047^{\star \star *} \\
(3.02)\end{array}$ & $\begin{array}{l}-0.080 \\
(-1.32)\end{array}$ & $\begin{array}{l}-0.037 \\
(-0.47)\end{array}$ & $\begin{array}{l}-0.037 \\
(-0.75)\end{array}$ & $\begin{array}{l}0.047^{* * *} \\
(3.18)\end{array}$ \\
\hline Mstp & $\begin{array}{l}0.018 \\
(0.82)\end{array}$ & \begin{tabular}{|l}
$-0.288^{\star * *}$ \\
$(-11.52)$
\end{tabular} & $\begin{array}{l}-0.130^{* \star *} \\
(-7.78)\end{array}$ & $\begin{array}{l}0.117^{\star \star \star} \\
(3.27)\end{array}$ & $\begin{array}{l}- \\
0.288^{\star \star \star *} \\
(-6.96)\end{array}$ & $\begin{array}{l}-0.067^{\star *} \\
(-2.48)\end{array}$ & $\begin{array}{l}-0.118^{\star \star \star} \\
(-8.27)\end{array}$ \\
\hline Yarp & $\begin{array}{l}0.030^{\star *} \\
(2.01) \\
\end{array}$ & \begin{tabular}{|l|}
0.046 \\
$(2.54)$ \\
\end{tabular} & $\begin{array}{l}0.039^{* * *} \\
(3.35)\end{array}$ & $\begin{array}{l}0.027 \\
(0.64)\end{array}$ & $\begin{array}{l}-0.044 \\
(-0.73)\end{array}$ & $\begin{array}{l}0.004 \\
(0.10)\end{array}$ & $\begin{array}{l}0.039^{* * *} \\
(3.53)\end{array}$ \\
\hline Dfamily & $\begin{array}{l}0.169^{* * *} \\
(7.62)\end{array}$ & $\begin{array}{l}0.124^{* * *} \\
(5.06)\end{array}$ & $\begin{array}{l}0.147^{* * *} \\
(8.82)\end{array}$ & $\begin{array}{l}0.059^{*} \\
(1.66)\end{array}$ & $\begin{array}{l}0.147^{* * *} \\
(3.61)\end{array}$ & $\begin{array}{l}0.093^{* * *} \\
(3.45)\end{array}$ & $\begin{array}{l}0.134^{* * *} \\
(9.51)\end{array}$ \\
\hline Govt & $\begin{array}{l}0.076^{* * *} \\
(3.09)\end{array}$ & $\begin{array}{l}0.094^{* * *} \\
(4.36)\end{array}$ & $\begin{array}{l}0.088^{* * *} \\
(5.42)\end{array}$ & $\begin{array}{l}0.132^{* * *} \\
(3.26)\end{array}$ & $\begin{array}{l}0.116^{\star * *} \\
(3.21)\end{array}$ & $\begin{array}{l}0.125^{* * *} \\
(4.66)\end{array}$ & $\begin{array}{l}0.097^{* * *} \\
(6.99)\end{array}$ \\
\hline Dmanager & $\begin{array}{l}0.581^{* * *} \\
(22.94)\end{array}$ & $\begin{array}{l}0.884^{\star * \star} \\
(22.18) \\
\end{array}$ & $\begin{array}{l}0.693^{\star * *} \\
(31.93)\end{array}$ & $\begin{array}{l}0.314^{\star \star \star} \\
(8.11)\end{array}$ & $\begin{array}{l}0.593^{\star \star \star} \\
(9.17)\end{array}$ & $\begin{array}{l}0.395^{\star * *} \\
(11.76)\end{array}$ & $\begin{array}{l}0.600^{* * *} \\
(32.96)\end{array}$ \\
\hline Dprof & $\begin{array}{l}0.568^{* * *} \\
(22.27)\end{array}$ & \begin{tabular}{|l}
$0.688^{* * *}$ \\
$(19.08)$
\end{tabular} & $\begin{array}{l}0.597^{\star \star *} \\
(28.64)\end{array}$ & $\begin{array}{l}0.379^{\star \star \star} \\
(7.20)\end{array}$ & $\begin{array}{l}0.534^{\star \star \star} \\
(8.04)\end{array}$ & $\begin{array}{l}0.416^{\star * \star} \\
(10.30)\end{array}$ & $\begin{array}{l}0.553^{* * *} \\
(29.99)\end{array}$ \\
\hline
\end{tabular}




\begin{tabular}{|c|c|c|c|c|c|c|c|}
\hline Dtach & $\begin{array}{l}0.278^{\star \star \star *} \\
(12.05) \\
\end{array}$ & $\begin{array}{l}0.389^{\star \star \star \star} \\
(8.10)\end{array}$ & $\begin{array}{l}0.314^{\star \star \star} \\
(14.92)\end{array}$ & $\begin{array}{l}0.304^{\star \star \star} \\
(8.04) \\
\end{array}$ & $\begin{array}{l}0.386^{\star \star \star} \\
(5.08) \\
\end{array}$ & $\begin{array}{l}0.310^{\star \star \star} \\
(9.11)\end{array}$ & $\begin{array}{l}0.311^{* \star \star} \\
(17.35)\end{array}$ \\
\hline Dcomper & $\begin{array}{l}0.087^{* *} \\
(2.40)\end{array}$ & $\begin{array}{l}0.188^{\star * \star} \\
(5.04)\end{array}$ & $\begin{array}{l}0.095^{\star \star \star} \\
(3.91)\end{array}$ & $\begin{array}{l}0.129^{\star} \\
(1.90)\end{array}$ & $\begin{array}{l}0.230^{* * *} \\
(3.78)\end{array}$ & $\begin{array}{l}0.143^{\star * \star} \\
(3.56)\end{array}$ & $\begin{array}{l}0.102^{\star \star \star} \\
(4.91)\end{array}$ \\
\hline Dclarical & $\begin{array}{l}0.333^{* * *} \\
(11.11)\end{array}$ & $\begin{array}{l}0.561^{* * *} \\
(16.74)\end{array}$ & $\begin{array}{l}0.414^{\star * \star} \\
(20.01)\end{array}$ & $\begin{array}{l}0.204^{* * *} \\
(3.22)\end{array}$ & $\begin{array}{l}0.515^{\star * *} \\
(8.89)\end{array}$ & $\begin{array}{l}0.363^{\star * \star} \\
(9.72)\end{array}$ & $\begin{array}{l}0.396^{\star * *} \\
(21.87)\end{array}$ \\
\hline Dsales & $\begin{array}{l}0.073^{* *} \\
(2.37)\end{array}$ & $\begin{array}{l}0.137^{\star * *} \\
(3.76)\end{array}$ & $\begin{array}{l}0.074^{\star * \star} \\
(3.25)\end{array}$ & $\begin{array}{l}0.041 \\
(0.72)\end{array}$ & $\begin{array}{l}0.050 \\
(0.80)\end{array}$ & $\begin{array}{l}0.007 \\
(0.17)\end{array}$ & $\begin{array}{l}0.052^{\star \star \star} \\
(2.65)\end{array}$ \\
\hline Dlabour & $\begin{array}{l}0.002 \\
(0.06)\end{array}$ & $\begin{array}{l}0.197^{\star * *} \\
(4.82)\end{array}$ & $\begin{array}{l}0.048^{* *} \\
(2.10)\end{array}$ & $\begin{array}{l}0.052 \\
(1.26)\end{array}$ & $\begin{array}{l}0.154^{* *} \\
(2.40)\end{array}$ & $\begin{array}{l}0.064 \\
(1.83) \\
\end{array}$ & $\begin{array}{l}0.059^{\star \star *} \\
(3.08)\end{array}$ \\
\hline Dmelbourne & & & & & & & $\begin{array}{l}0.121^{* * *} \\
(11.50)\end{array}$ \\
\hline Constant & $\begin{array}{l}3.997^{* * *} \\
(56.73)\end{array}$ & $\begin{array}{l}3.866^{* * *} \\
(44.75)\end{array}$ & $\begin{array}{l}3.767^{* * *} \\
(67.77)\end{array}$ & $\begin{array}{l}4.388^{* * \star} \\
(29.47)\end{array}$ & $\begin{array}{l}4.537^{* * \star} \\
(21.66)\end{array}$ & $\begin{array}{l}4.197^{* * *} \\
(34.10)\end{array}$ & $\begin{array}{l}3.719^{* * *} \\
(74.11)\end{array}$ \\
\hline Adjusted $\mathrm{R}^{2}$ & 0.393 & 0.350 & 0.388 & 0.268 & 0.267 & 0.301 & 0.367 \\
\hline F-stat & $213.43^{\star \star \star}$ & $155.77^{\star \star \star}$ & $377.67^{\star \star \star}$ & $42.87^{\star * \star}$ & $34.86^{* \star *}$ & $86.81^{* * *}$ & $444.95^{\star \star \star}$ \\
\hline $\begin{array}{l}\text { No. of } \\
\text { Observations }\end{array}$ & 8549 & 7475 & 16024 & 2968 & 2420 & 5388 & 21412 \\
\hline Threshold Age & 47.38 & 47.25 & 47.56 & 46.19 & 46.96 & 46.69 & 47.20 \\
\hline
\end{tabular}

Figures in brackets indicate $p$-values.

${ }^{* * *},{ }^{* *},{ }^{*}$ indicates significant at $1 \%, 5 \%$ and $10 \%$ level respectively.

Chinese born immigrants experienced income discrimination in both metropolitan regions (Sydney and Melbourne), but not consistently in regional areas. Language spoken at home did impact in cities, but not in regional areas. English being the first language certainly acted as an advantage for both men and women in Sydney and Melbourne. A shortage of skilled manpower in regional Australia is a possible explanation for the higher income earning ability of the non-English speaking population in the regions. In terms of occupation structure, little difference is observed between regions or genders. In general, higher status positions (e.g. professionals and managers) had higher earnings outcomes in both regions.

As already indicated, differences in wages are usually less prominent in Australia due to its non-discriminatory wage policies. However, some differences still exist due to unorganised activities in certain labour markets - particularly in cities and because of the potential to discriminate in the payment of above award wages. As Tables 4 and 5 indicate, men with lower level educational qualifications experienced wage disadvantages in metropolitan areas compared with women. This might be due to women workers dominating employment in the retail and tourism industries in metropolitan cities. The findings for regional areas were mixed - no consistent trend could be observed regarding discrimination. Asian (India and South East Asia) and Chinese born women immigrants experienced wage discrimination in both metropolitan regions, but not in regional areas (RNSW and RVIC). A shortage of skilled labour in regional areas might explain the reduced experience of discrimination for these groups in regional areas as compared to cities where the large scale availability of professionals at different levels possibly 
resulted in positive discrimination against women. Asian and Chinese male immigrants experienced wage disadvantages in SYD, MELB and RNSW regions, but not in RVIC.

The findings with respect to age are consistent for both genders in both regions. In all regions, the impact of Age and $\mathrm{Age}^{2}$ conformed to expectations with both dependent variables being positively impacted at first but with a subsequent negative impact at older age levels. Threshold ages, where the response of the dependent variable to a change in age reverses, are consistently higher for wages than income levels in both regions. Again, threshold ages are higher for men in metropolitan cities, but in regions it is higher for women - except in case of RNSW. Interestingly, threshold ages are found to be consistently higher in metropolitan cities than regional areas for both income and wage. Limited job opportunities, lack of business environment and unprofitable agricultural activities due to severe drought conditions may have contributed to this.

\section{Table 4 Estimated coefficients of labour market outcome - Wage - Sydney and Other NSW (Heckman-twostep)}

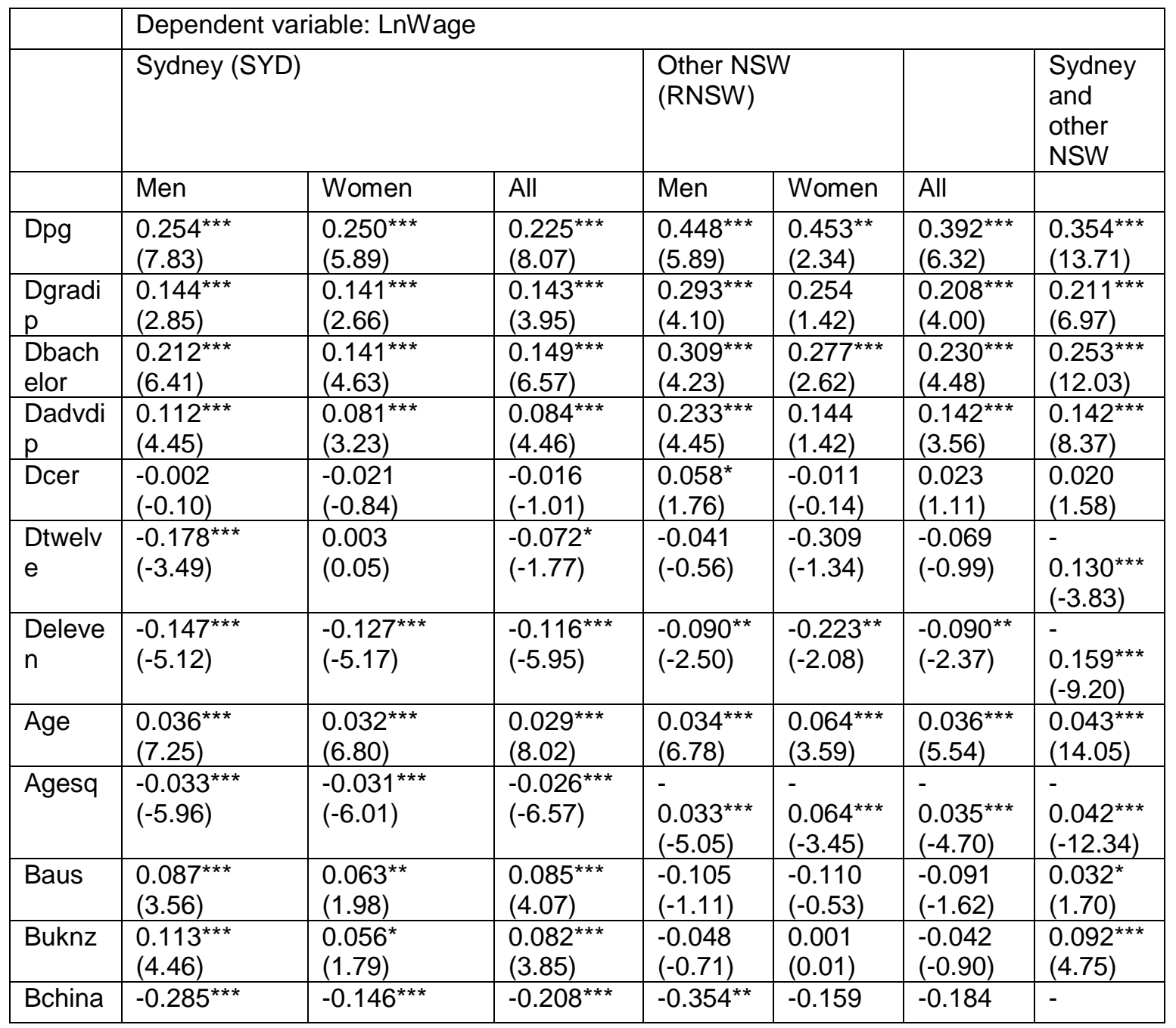




\begin{tabular}{|c|c|c|c|c|c|c|c|}
\hline & $(-8.42)$ & $(-3.12)$ & $(-7.12)$ & $(-2.10)$ & $(-0.25)$ & $(-1.32)$ & $\begin{array}{l}0.266^{\star \star \star} \\
(-9.00)\end{array}$ \\
\hline Basia & $\begin{array}{l}-0.070^{\star *} \\
(-2.23)\end{array}$ & $\begin{array}{l}0.000 \\
(-0.01)\end{array}$ & $\begin{array}{l}-0.056^{\star * *} \\
(-2.71)\end{array}$ & $\begin{array}{l}-0.212^{*} \\
(-1.85)\end{array}$ & $\begin{array}{l}-0.047 \\
(-0.13)\end{array}$ & $\begin{array}{l}-0.028 \\
(-0.37)\end{array}$ & $\begin{array}{l}-0.049^{\star \star} \\
(-2.40)\end{array}$ \\
\hline $\begin{array}{l}\text { Beuro } \\
\text { pe }\end{array}$ & $\begin{array}{l}0.023 \\
(0.55)\end{array}$ & $\begin{array}{l}-0.037 \\
(-0.57)\end{array}$ & $\begin{array}{l}-0.018 \\
(-0.49)\end{array}$ & $\begin{array}{l}-0.099 \\
(-0.94)\end{array}$ & $\begin{array}{l}-0.120 \\
(-0.40)\end{array}$ & $\begin{array}{l}-0.144^{*} \\
(-1.86)\end{array}$ & $\begin{array}{l}0.055 \\
1.580\end{array}$ \\
\hline $\begin{array}{l}\text { Gende } \\
\mathrm{rp}\end{array}$ & & & $\begin{array}{l}0.069^{\star \star \star} \\
(6.61)\end{array}$ & & & $\begin{array}{l}0.047^{\star \star \star} \\
(3.19)\end{array}$ & $\begin{array}{l}0.076^{\star \star \star} \\
(8.81)\end{array}$ \\
\hline Lanp & $\begin{array}{l}0.079^{\star \star *} \\
(2.99)\end{array}$ & $\begin{array}{l}0.050^{*} \\
(1.83)\end{array}$ & $\begin{array}{l}0.040^{* *} \\
(2.08)\end{array}$ & $\begin{array}{l}0.056 \\
(1.25)\end{array}$ & $\begin{array}{l}0.043 \\
(0.31)\end{array}$ & $\begin{array}{l}0.035 \\
(1.04)\end{array}$ & $\begin{array}{l}0.110^{\star \star \star} \\
(6.35)\end{array}$ \\
\hline Mstp & 0.029 & 0.025 & 0.022 & 0.048 & 0.031 & 0.024 & 0.028 \\
\hline Yarp & $\begin{array}{l}-0.017 \\
(-1.00)\end{array}$ & $\begin{array}{l}-0.018 \\
(-0.91)\end{array}$ & $\begin{array}{l}-0.033^{* *} \\
(-2.51)\end{array}$ & $\begin{array}{l}-0.002 \\
(-0.04)\end{array}$ & $\begin{array}{l}0.114 \\
(0.91)\end{array}$ & $\begin{array}{l}0.011 \\
(0.46)\end{array}$ & $\begin{array}{l}0.016 \\
(1.39)\end{array}$ \\
\hline $\begin{array}{l}\text { Dfamil } \\
\mathrm{y}\end{array}$ & $\begin{array}{l}0.095^{\star \star \star} \\
(3.38)\end{array}$ & $\begin{array}{l}0.015 \\
(0.67)\end{array}$ & $\begin{array}{l}0.036^{* *} \\
(2.00)\end{array}$ & $\begin{array}{l}0.041 \\
(1.11)\end{array}$ & $\begin{array}{l}0.055 \\
(0.52)\end{array}$ & $\begin{array}{l}-0.012 \\
(-0.33)\end{array}$ & $\begin{array}{l}0.065^{\star \star \star} \\
(4.04)\end{array}$ \\
\hline Govt & $\begin{array}{l}0.101^{* * *} \\
(5.62)\end{array}$ & $\begin{array}{l}0.047^{* * *} \\
(2.61)\end{array}$ & $\begin{array}{l}0.071^{\text {** }} \\
(5.52)\end{array}$ & $\begin{array}{l}0.182^{* * *} \\
98.12)\end{array}$ & $\begin{array}{l}0.108^{*} \\
(1.86)\end{array}$ & $\begin{array}{l}0.146^{\star * *} \\
(9.200\end{array}$ & $\begin{array}{l}0.103^{* \star \star} \\
(10.23)\end{array}$ \\
\hline $\begin{array}{l}\text { Dman } \\
\text { ager }\end{array}$ & $\begin{array}{l}0.314^{\star \star \star} \\
(14.44)\end{array}$ & $\begin{array}{l}0.300^{\star \star \star} \\
(7.14)\end{array}$ & $\begin{array}{l}0.329^{\star \star \star} \\
(17.43)\end{array}$ & $\begin{array}{l}-0.063^{* *} \\
(-2.37)\end{array}$ & $\begin{array}{l}-0.066 \\
(-0.37)\end{array}$ & $\begin{array}{l}-0.055^{\star \star} \\
(-2.22)\end{array}$ & $\begin{array}{l}0.174^{\star \star \star} \\
(11.54)\end{array}$ \\
\hline Dprof & $\begin{array}{l}0.351^{* \star *} \\
(16.16)\end{array}$ & $\begin{array}{l}0.273^{\star \star *} \\
(6.78)\end{array}$ & $\begin{array}{l}0.336^{\star * \star} \\
(18.25)\end{array}$ & $\begin{array}{l}0.124^{\star \star \star} \\
(3.91)\end{array}$ & $\begin{array}{l}0.106 \\
(0.60)\end{array}$ & $\begin{array}{l}0.127^{\star * \star} \\
(4.73)\end{array}$ & $\begin{array}{l}0.252^{\star \star \star} \\
(16.48)\end{array}$ \\
\hline Dtach & $\begin{array}{l}0.048^{\star *} \\
(2.30)\end{array}$ & $\begin{array}{l}-0.026 \\
(-0.54)\end{array}$ & $\begin{array}{l}0.038^{\star *} \\
(2.03)\end{array}$ & $\begin{array}{l}- \\
0.089^{\star \star *} \\
(-3.56)\end{array}$ & $\begin{array}{l}-0.195 \\
(-1.03)\end{array}$ & $\begin{array}{l}- \\
0.101^{\star * *} \\
(-4.18)\end{array}$ & $\begin{array}{l}-0.018 \\
(-1.19)\end{array}$ \\
\hline $\begin{array}{l}\text { Dcomp } \\
\text { er }\end{array}$ & $\begin{array}{l}0.053^{*} \\
(1.82)\end{array}$ & $\begin{array}{l}-0.024 \\
(-0.58)\end{array}$ & $\begin{array}{l}0.038^{*} \\
(1.82)\end{array}$ & $\begin{array}{l}-0.036 \\
(-0.96)\end{array}$ & $\begin{array}{l}-0.114 \\
(-0.66)\end{array}$ & $\begin{array}{l}-0.067^{* *} \\
(-2.45)\end{array}$ & $\begin{array}{l}-0.004 \\
(-0.21)\end{array}$ \\
\hline $\begin{array}{l}\text { Dclaric } \\
\text { al }\end{array}$ & $\begin{array}{l}0.155^{\star \star \star} \\
(6.33)\end{array}$ & $\begin{array}{l}0.125^{\star \star \star} \\
(3.20)\end{array}$ & $\begin{array}{l}0.170^{\star \star \star} \\
(9.29)\end{array}$ & $\begin{array}{l}-0.021 \\
(-0.53) \\
\end{array}$ & $\begin{array}{l}-0.022 \\
(-0.13) \\
\end{array}$ & $\begin{array}{l}-0.004 \\
(-0.14)\end{array}$ & $\begin{array}{l}0.099^{* \star \star} \\
(6.57)\end{array}$ \\
\hline Dsales & $\begin{array}{l}0.073^{\star * *} \\
(2.83)\end{array}$ & $\begin{array}{l}-0.019 \\
(-0.47)\end{array}$ & $\begin{array}{l}0.054^{\star * *} \\
(2.71)\end{array}$ & $\begin{array}{l}0.093^{* * *} \\
(-2.79)\end{array}$ & $\begin{array}{l}-0.127 \\
(-0.73)\end{array}$ & $\begin{array}{l}0.090^{\star * *} \\
(-3.38)\end{array}$ & $\begin{array}{l}-0.007 \\
(0.43)\end{array}$ \\
\hline $\begin{array}{l}\text { Dlabou } \\
r\end{array}$ & $\begin{array}{l}0.013 \\
(0.54)\end{array}$ & $\begin{array}{l}-0.041 \\
(-0.91)\end{array}$ & $\begin{array}{l}0.009 \\
(0.44)\end{array}$ & $\begin{array}{l}0.140^{\star * *} \\
(-5.13)\end{array}$ & $\begin{array}{l}-0.051 \\
(-0.29)\end{array}$ & $\begin{array}{l}0.099^{\star * *} \\
(-3.96)\end{array}$ & $\begin{array}{l}-0.032^{\star *} \\
(-2.03)\end{array}$ \\
\hline $\begin{array}{l}\text { Dsydn } \\
\text { ey }\end{array}$ & & & & & & & $\begin{array}{l}0.128^{\star \star \star} \\
(8.41)\end{array}$ \\
\hline $\begin{array}{l}\text { Consta } \\
\text { nt }\end{array}$ & $\begin{array}{l}1.964^{* * *} \\
(8.46)\end{array}$ & $\begin{array}{l}2.287^{* * *} \\
(10.37)\end{array}$ & $\begin{array}{l}2.330^{\star * *} \\
(14.33)\end{array}$ & $\begin{array}{l}2.178^{* * *} \\
(9.22)\end{array}$ & $\begin{array}{l}0.805 \\
(0.84)\end{array}$ & $\begin{array}{l}2.200^{* * *} \\
(6.48)\end{array}$ & $\begin{array}{l}1.524^{\star \star \star} \\
(9.48)\end{array}$ \\
\hline Mills $\lambda$ & $\begin{array}{l}0.062 \\
(0.19)\end{array}$ & $\begin{array}{l}-0.463 \\
(-1.32)\end{array}$ & $\begin{array}{l}-0.568^{* *} \\
(-2.44)\end{array}$ & $\begin{array}{l}0.252 \\
(0.52)\end{array}$ & $\begin{array}{l}1.635 \\
(1.39)\end{array}$ & $\begin{array}{l}-0.097 \\
(-0.17)\end{array}$ & $\begin{array}{l}0.558^{* *} \\
(2.55) \mathrm{t} \\
\text { value }\end{array}$ \\
\hline$\chi^{2}$ & $1418.65^{* * *}$ & $887.09^{* * *}$ & $\begin{array}{l}1825.46^{* *} \\
*\end{array}$ & $\begin{array}{l}789.58^{* *} \\
*\end{array}$ & $65.43^{* * *}$ & $\begin{array}{l}987.49^{* *} \\
\end{array}$ & $\underbrace{2320.86}_{* * *}$ \\
\hline $\begin{array}{l}\text { No of } \\
\text { observ } \\
\text { ations }\end{array}$ & 9,426 & 7,944 & 17,370 & 6,019 & 5,048 & 11,067 & 28,437 \\
\hline $\begin{array}{l}\text { Thresh } \\
\text { old } \\
\text { Age }\end{array}$ & 54.64 & 51.77 & 55.62 & 51.53 & 49.68 & 51.29 & 51.31 \\
\hline
\end{tabular}

Figures in brackets indicate $p$-values.

${ }^{* * *},{ }^{* *},{ }^{*}$ indicates significant at $1 \%, 5 \%$ and $10 \%$ level respectively. 
Table 5: Estimated coefficients of labour market outcome - Wage - Melbourne and Victoria (Heckman-twostep)

\begin{tabular}{|c|c|c|c|c|c|c|c|}
\hline & \multicolumn{3}{|c|}{ Melbourne (MELB) } & \multicolumn{3}{|c|}{ Other Victoria (RVIC) } & \multirow{2}{*}{$\begin{array}{l}\text { Melbourne } \\
\text { and other } \\
\text { Victoria }\end{array}$} \\
\hline & Men & Women & All & Men & Women & all & \\
\hline Dpg & $\begin{array}{l}0.330^{* * *} \\
(7.04)\end{array}$ & $\begin{array}{l}0.417^{* * *} \\
(7.48)\end{array}$ & $\begin{array}{l}0.347^{* * *} \\
(12.30)\end{array}$ & $\begin{array}{l}0.508^{* * *} \\
(2.63)\end{array}$ & $\begin{array}{l}0.281^{*} \\
(1.98)\end{array}$ & $\begin{array}{l}0.413^{* *} \\
(2.32) \\
\end{array}$ & $\begin{array}{l}0.387^{* * *} \\
(11.50)\end{array}$ \\
\hline Dgradip & $\begin{array}{l}0.259^{\star * \star} \\
(3.26)\end{array}$ & $\begin{array}{l}0.281^{* * *} \\
(5.52)\end{array}$ & $\begin{array}{l}0.229^{\star \star \star} \\
(6.80)\end{array}$ & $\begin{array}{l}0.261 \\
(1.47)\end{array}$ & $\begin{array}{l}0.236^{*} \\
(1.67)\end{array}$ & $\begin{array}{l}0.267 \\
(1.54)\end{array}$ & $\begin{array}{l}0.257^{\star \star \star} \\
(6.46)\end{array}$ \\
\hline Dbachelor & $\begin{array}{l}0.210^{\star \star *} \\
(5.54)\end{array}$ & $\begin{array}{l}0.254^{* * *} \\
(7.87)\end{array}$ & $\begin{array}{l}0.212^{\star \star \star} \\
(10.87)\end{array}$ & $\begin{array}{l}0.301^{\star \star \star} \\
(2.67)\end{array}$ & $\begin{array}{l}0.234^{* \star *} \\
(3.08)\end{array}$ & $\begin{array}{l}0.277^{\star \star *} \\
(2.95)\end{array}$ & $\begin{array}{l}0.241^{* * *} \\
(10.77)\end{array}$ \\
\hline Dadvdip & $\begin{array}{l}0.121^{\text {** }} \\
(3.37) \\
\end{array}$ & $\begin{array}{l}0.129^{\star \star \star} \\
(4.16)\end{array}$ & $\begin{array}{l}0.115^{\star \star *} \\
(6.28)\end{array}$ & $\begin{array}{l}0.195^{\star \star} \\
(2.09) \\
\end{array}$ & $\begin{array}{l}0.099 \\
(1.10) \\
\end{array}$ & $\begin{array}{l}0.160 \\
(1.66) \\
\end{array}$ & $\begin{array}{l}0.129^{\star \star \star} \\
(5.96)\end{array}$ \\
\hline Dcer & $\begin{array}{l}0.031 \\
(1.00)\end{array}$ & $\begin{array}{l}0.026 \\
(0.83)\end{array}$ & $\begin{array}{l}0.021 \\
(1.23)\end{array}$ & $\begin{array}{l}0.063 \\
(1.09)\end{array}$ & $\begin{array}{l}0.034 \\
(0.50)\end{array}$ & $\begin{array}{l}0.055 \\
(0.96)\end{array}$ & $\begin{array}{l}0.046^{* \star *} \\
(2.64)\end{array}$ \\
\hline Dtwelve & $\begin{array}{l}-0.090 \\
(-1.29) \\
\end{array}$ & $\begin{array}{l}-0.005 \\
(-0.08) \\
\end{array}$ & $\begin{array}{l}-0.041 \\
(-1.18) \\
\end{array}$ & $\begin{array}{l}-0.405 \\
(-1.41) \\
\end{array}$ & $\begin{array}{l}-0.083 \\
(-0.41) \\
\end{array}$ & $\begin{array}{l}-0.348 \\
(-1.18) \\
\end{array}$ & $\begin{array}{l}-0.095^{\star \star} \\
(-2.18)\end{array}$ \\
\hline Deleven & $\begin{array}{l}-0.217^{\star \star *} \\
(-3.48)\end{array}$ & $\begin{array}{l}-0.139^{\star * *} \\
(-4.98)\end{array}$ & $\begin{array}{l}-0.151^{\star * *} \\
(-6.50)\end{array}$ & $\begin{array}{l}-0.225^{*} \\
(-1.91)\end{array}$ & $\begin{array}{l}-0.050 \\
(-0.70)\end{array}$ & $\begin{array}{l}-0.178 \\
(-1.52)\end{array}$ & $\begin{array}{l}-0.167^{* \star *} \\
(-6.40)\end{array}$ \\
\hline Age & $\begin{array}{l}0.040^{\star * *} \\
(5.54) \\
\end{array}$ & $\begin{array}{l}0.041^{* * *} \\
(6.53)\end{array}$ & $\begin{array}{l}0.036^{\star * *} \\
(9.43)\end{array}$ & $\begin{array}{l}0.044^{\star * *} \\
(2.98)\end{array}$ & $\begin{array}{l}0.040^{\star \star \star} \\
(2.84)\end{array}$ & $\begin{array}{l}0.049^{\star *} \\
(2.32)\end{array}$ & $\begin{array}{l}0.042^{\star \star \star} \\
(9.34)\end{array}$ \\
\hline Agesq & $\begin{array}{l}-0.038^{\star \star \star} \\
(-4.58)\end{array}$ & $\begin{array}{l}-0.039^{\star \star \star} \\
(-5.70)\end{array}$ & $\begin{array}{l}-0.033^{\star \star \star} \\
(-7.91)\end{array}$ & $\begin{array}{l}-0.044^{\star \star} \\
(-2.40)\end{array}$ & $\begin{array}{l}- \\
0.038^{* * *} \\
(-2.57)\end{array}$ & $\begin{array}{l}-0.049^{\star \star} \\
(-2.07)\end{array}$ & $\begin{array}{l}-0.040^{\star * \star} \\
(-8.15)\end{array}$ \\
\hline Baus & $\begin{array}{l}0.023 \\
(0.56) \\
\end{array}$ & $\begin{array}{l}0.010 \\
(0.27)\end{array}$ & $\begin{array}{l}0.015 \\
(0.69)\end{array}$ & $\begin{array}{l}0.160 \\
(0.96)\end{array}$ & $\begin{array}{l}0.070 \\
(0.39)\end{array}$ & $\begin{array}{l}0.117 \\
(0.69)\end{array}$ & $\begin{array}{l}0.025 \\
(0.93)\end{array}$ \\
\hline Buknz & $\begin{array}{l}0.090^{* *} \\
(2.03) \\
\end{array}$ & $\begin{array}{l}0.082^{* \star} \\
(1.98) \\
\end{array}$ & $\begin{array}{l}0.073^{\star \star *} \\
(3.19)\end{array}$ & $\begin{array}{l}0.061 \\
(0.43) \\
\end{array}$ & $\begin{array}{l}0.009 \\
(0.06)\end{array}$ & $\begin{array}{l}0.052 \\
(0.36) \\
\end{array}$ & $\begin{array}{l}0.075^{\star \star \star} \\
(2.67)\end{array}$ \\
\hline Bchina & $\begin{array}{l}-0.221^{\star *} \\
(-2.33)\end{array}$ & $\begin{array}{l}-0.212^{\star \star \star} \\
(-2.61)\end{array}$ & $\begin{array}{l}-0.166^{\star \star \star} \\
(-3.41)\end{array}$ & $\begin{array}{l}-0.002 \\
(-0.00)\end{array}$ & $\begin{array}{l}-0.244 \\
(-0.38)\end{array}$ & $\begin{array}{l}-0.166 \\
(-0.31)\end{array}$ & $\begin{array}{l}-0.215^{\star \star \star} \\
(-3.58)\end{array}$ \\
\hline Basia & $\begin{array}{l}-0.024 \\
(-0.58) \\
\end{array}$ & $\begin{array}{l}0.012 \\
(0.30) \\
\end{array}$ & $\begin{array}{l}-0.011 \\
(-0.51)\end{array}$ & $\begin{array}{l}0.042 \\
(0.13)\end{array}$ & $\begin{array}{l}0.276 \\
(0.86) \\
\end{array}$ & $\begin{array}{l}0.143 \\
(0.46) \\
\end{array}$ & $\begin{array}{l}-0.005 \\
(-0.19) \\
\end{array}$ \\
\hline Beurope & $\begin{array}{l}-0.049 \\
(-0.95) \\
\end{array}$ & $\begin{array}{l}0.013 \\
(0.23) \\
\end{array}$ & $\begin{array}{l}-0.030 \\
(-1.03) \\
\end{array}$ & $\begin{array}{l}0.093 \\
(0.44) \\
\end{array}$ & $\begin{array}{l}-0.400 \\
(-1.28) \\
\end{array}$ & $\begin{array}{l}-0.066 \\
(-0.27) \\
\end{array}$ & $\begin{array}{l}-0.019 \\
(-0.52) \\
\end{array}$ \\
\hline Genderp & & & $\begin{array}{l}0.087^{\star * *} \\
(9.14)\end{array}$ & & & $\begin{array}{l}0.105 \\
(1.20)\end{array}$ & $\begin{array}{l}0.086^{\star \star \star} \\
(7.09)\end{array}$ \\
\hline Lanp & \begin{tabular}{|l}
$0.087^{* *}$ \\
$(3.00)$ \\
\end{tabular} & $\begin{array}{l}0.089^{\star * *} \\
(2.91)\end{array}$ & $\begin{array}{l}0.076^{\star * *} \\
(4.65)\end{array}$ & $\begin{array}{l}0.034 \\
(0.27) \\
\end{array}$ & $\begin{array}{l}0.160 \\
(1.00) \\
\end{array}$ & $\begin{array}{l}0.119 \\
(0.72) \\
\end{array}$ & $\begin{array}{l}0.094^{* \star \star} \\
(4.40)\end{array}$ \\
\hline Mstp & $\begin{array}{l}0.030 \\
(1.05)\end{array}$ & $\begin{array}{l}-0.063 \\
(-1.56)\end{array}$ & $\begin{array}{l}-0.003 \\
(-0.18)\end{array}$ & $\begin{array}{l}0.118 \\
(0.92)\end{array}$ & $\begin{array}{l}0.046 \\
(0.67)\end{array}$ & $\begin{array}{l}0.112 \\
(1.03)\end{array}$ & $\begin{array}{l}0.006 \\
(0.35)\end{array}$ \\
\hline Yarp & $\begin{array}{l}0.031 \\
(1.35) \\
\end{array}$ & $\begin{array}{l}0.033 \\
(1.41) \\
\end{array}$ & $\begin{array}{l}0.022^{*} \\
(1.78)\end{array}$ & $\begin{array}{l}-0.012 \\
(-0.12) \\
\end{array}$ & $\begin{array}{l}-0.002 \\
(-0.02) \\
\end{array}$ & $\begin{array}{l}0.003 \\
(0.03)\end{array}$ & $\begin{array}{l}0.030^{*} \\
(1.91)\end{array}$ \\
\hline Dfamily & $\begin{array}{l}0.141^{\star \star \star} \\
(2.58) \\
\end{array}$ & $\begin{array}{l}0.065^{\star} \\
(1.75)\end{array}$ & $\begin{array}{l}0.072^{\star \star \star} \\
(2.98)\end{array}$ & $\begin{array}{l}0.025 \\
(0.35) \\
\end{array}$ & $\begin{array}{l}-0.013 \\
(-0.20) \\
\end{array}$ & $\begin{array}{l}0.006 \\
(0.09) \\
\end{array}$ & $\begin{array}{l}0.076^{\star \star \star} \\
(3.23)\end{array}$ \\
\hline Govt & $\begin{array}{l}0.069^{* \star} \\
(2.48)\end{array}$ & $\begin{array}{l}0.014 \\
(0.73)\end{array}$ & $\begin{array}{l}0.033^{* *} \\
(2.47)\end{array}$ & $\begin{array}{l}0.078 \\
(1.25)\end{array}$ & $\begin{array}{l}0.053 \\
(1.11)\end{array}$ & $\begin{array}{l}0.066 \\
(1.24)\end{array}$ & $\begin{array}{l}0.043^{* * *} \\
(3.02)\end{array}$ \\
\hline Dmanager & $\begin{array}{l}0.240^{* * *} \\
(7.98)\end{array}$ & $\begin{array}{l}0.196^{\star * *} \\
(4.25)\end{array}$ & $\begin{array}{l}0.238^{* * *} \\
(12.11)\end{array}$ & $\begin{array}{l}-0.066 \\
(-1.02) \\
\end{array}$ & $\begin{array}{l}-0.091 \\
(-0.73) \\
\end{array}$ & $\begin{array}{l}-0.058 \\
(-0.76) \\
\end{array}$ & 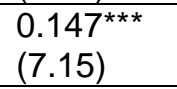 \\
\hline Dprof & $\begin{array}{l}0.311^{\star \star \star} \\
(10.24)\end{array}$ & $\begin{array}{l}0.206^{\star \star \star} \\
(4.70)\end{array}$ & $\begin{array}{l}0.276^{\star \star \star} \\
(14.38)\end{array}$ & $\begin{array}{l}0.119 \\
(1.38)\end{array}$ & $\begin{array}{l}0.083 \\
(0.67)\end{array}$ & $\begin{array}{l}0.127 \\
(1.42)\end{array}$ & $\begin{array}{l}0.235^{\star \star \star} \\
(11.22)\end{array}$ \\
\hline Dtach & $\begin{array}{l}0.012 \\
(0.42) \\
\end{array}$ & $\begin{array}{l}-0.065 \\
(-1.26) \\
\end{array}$ & $\begin{array}{l}0.001 \\
(0.03) \\
\end{array}$ & $\begin{array}{l}-0.042 \\
(-0.66) \\
\end{array}$ & $\begin{array}{l}-0.103 \\
(-0.77) \\
\end{array}$ & $\begin{array}{l}-0.049 \\
(-0.65) \\
\end{array}$ & $\begin{array}{l}-0.016 \\
(-0.78) \\
\end{array}$ \\
\hline Dcomper & $\begin{array}{l}0.048 \\
(1.16)\end{array}$ & $\begin{array}{l}0.010 \\
(0.22)\end{array}$ & $\begin{array}{l}0.050^{* *} \\
(2.32)\end{array}$ & $\begin{array}{l}0.040 \\
(0.38)\end{array}$ & $\begin{array}{l}-0.073 \\
(-0.61) \\
\end{array}$ & $\begin{array}{l}0.001 \\
(0.01)\end{array}$ & $\begin{array}{l}0.035 \\
(1.55) \\
\end{array}$ \\
\hline
\end{tabular}




\begin{tabular}{|c|c|c|c|c|c|c|c|}
\hline Dclarical & $\begin{array}{l}0.101^{* * *} \\
(2.92)\end{array}$ & $\begin{array}{l}0.116^{* * *} \\
(2.78) \\
\end{array}$ & $\begin{array}{l}0.135^{\star * *} \\
(7.10)\end{array}$ & $\begin{array}{l}-0.025 \\
(-0.25) \\
\end{array}$ & $\begin{array}{l}0.014 \\
(0.12) \\
\end{array}$ & $\begin{array}{l}0.044 \\
(0.54) \\
\end{array}$ & $\begin{array}{l}0.108^{* * *} \\
(5.25)\end{array}$ \\
\hline Dsales & $\begin{array}{l}0.050 \\
(1.42)\end{array}$ & $\begin{array}{l}-0.012 \\
(-0.28)\end{array}$ & $\begin{array}{l}0.039^{*} \\
(1.91)\end{array}$ & $\begin{array}{l}-0.076 \\
(-0.84)\end{array}$ & $\begin{array}{l}-0.190 \\
(-1.58)\end{array}$ & $\begin{array}{l}-0.102 \\
(-1.18)\end{array}$ & $\begin{array}{l}0.001 \\
(0.04)\end{array}$ \\
\hline Dlabour & $\begin{array}{l}-0.011 \\
(-0.35) \\
\end{array}$ & $\begin{array}{l}-0.019 \\
(-0.41)\end{array}$ & $\begin{array}{l}-0.006 \\
(-0.29) \\
\end{array}$ & $\begin{array}{l}-0.035 \\
(-0.52) \\
\end{array}$ & $\begin{array}{l}-0.049 \\
(-0.40) \\
\end{array}$ & $\begin{array}{l}-0.023 \\
(-0.30) \\
\end{array}$ & $\begin{array}{l}-0.004 \\
(-0.17) \\
\end{array}$ \\
\hline Dmelbourne & & & & & & & $\begin{array}{l}0.105^{\star * *} \\
(6.69)\end{array}$ \\
\hline Constant & $\begin{array}{l}1.561^{* * *} \\
(4.80)\end{array}$ & $\begin{array}{l}1.600^{* * *} \\
(5.74)\end{array}$ & $\begin{array}{l}1.759^{* * *} \\
(10.41)\end{array}$ & $\begin{array}{l}1.588^{*} \\
(1.90)\end{array}$ & $\begin{array}{l}1.601^{* *} \\
(2.23)\end{array}$ & $\begin{array}{l}1.200 \\
(1.03)\end{array}$ & $\begin{array}{l}1.424^{* * *} \\
(6.69)\end{array}$ \\
\hline Mills $\lambda$ & $\begin{array}{l}0.765 \\
(0.13)\end{array}$ & $\begin{array}{l}0.652^{*} \\
(0.08)\end{array}$ & $\begin{array}{l}0.336 \\
(0.17)\end{array}$ & $\begin{array}{l}1.092 \\
(0.40)\end{array}$ & $\begin{array}{l}0.974 \\
(0.21) \\
\end{array}$ & $\begin{array}{l}1.437 \\
(0.34)\end{array}$ & $\begin{array}{l}0.728^{* \star} \\
(0.01) \\
\end{array}$ \\
\hline$\chi^{2}$ & $607.38^{\star * \star}$ & $571.13^{* * *}$ & $1761.18^{\star \star \star}$ & $81.79^{\star * \star}$ & $70.92^{\star \star \star}$ & $63.39^{* * *}$ & $1104.96^{\star * \star}$ \\
\hline $\begin{array}{l}\text { No of } \\
\text { observations }\end{array}$ & 8754 & 7663 & 16417 & 3035 & 2480 & 5515 & 21932 \\
\hline $\begin{array}{l}\text { Threshold } \\
\text { age }\end{array}$ & 53.31 & 52.82 & 54.74 & 49.21 & 51.96 & 50.00 & 52.36 \\
\hline
\end{tabular}

Figures in brackets indicate p-values.

${ }^{* * *},{ }^{* *},{ }^{*}$ indicates significant at $1 \%, 5 \%$ and $10 \%$ level respectively

This study uses Blinder-Oaxaca decomposition analysis to explore the level of discrimination further. Table 6 presents the results of Blinder-Oaxaca decomposition. A three-fold decomposition is performed here. The analysis first estimated coefficients of the raw differences between men and women in weekly income and average hourly wage rates (results presented under Difference heading in Table 6), and then decomposed the coefficients into three parts. Part 1, referred to as 'Explained' in Table 6, is that part of the raw differences explained by differences in endowments (education, age etc.); part 2 is the 'coefficient' effect (also known as the 'unexplained' differential) which measures the contribution of differences in the coefficients which is unexplained by endowments; and part 3 is the interaction coefficient. Results obtained under parts 2 and 3 are combined and presented under the 'Unexplained' heading in Table 6 as values of the interaction coefficients (part 3) were found to be very small in all cases. The 'Unexplained' component can be treated as the measure of discrimination and provides a better understanding of the reasons why women had lower mean rates of pay and income than men. 
Table 6: Estimates from the Blinder-Oaxaca Decomposition (Coefficients

\begin{tabular}{|c|c|c|c|c|c|c|}
\hline \multicolumn{7}{|c|}{ Part 1: Average weekly income } \\
\hline & $\begin{array}{l}\text { Sydney } \\
\text { (SYD) }\end{array}$ & $\begin{array}{l}\text { Other NSW } \\
\text { (RNSW) }\end{array}$ & Combined & $\begin{array}{l}\text { Melbourne } \\
\text { (MELB) }\end{array}$ & $\begin{array}{l}\text { Other } \\
\text { Victoria } \\
\text { (RVIC) }\end{array}$ & Combined \\
\hline Men & $6.734^{* * *}$ & $6.535^{\star \star *}$ & $6.656^{\star \star \star}$ & $6.653^{\star * \star}$ & $6.525^{\star \star \star}$ & $6.620^{\star * *}$ \\
\hline Women & $6.482^{\star \star \star}$ & $6.162^{\star \star \star}$ & $6.351^{\star \star \star}$ & $6.301^{\star * *}$ & $6.138^{\star \star \star}$ & $6.261^{\star \star \star}$ \\
\hline Difference & $0.252^{* * *}$ & $0.373^{* * *}$ & $0.305^{\star * *}$ & $0.352^{* * *}$ & $0.387^{* * *}$ & $0.359^{* * *}$ \\
\hline Explained & $0.047^{* * *}$ & $0.038^{* *}$ & $0.037^{* * *}$ & 0.010 & 0.025 & $0.016^{*}$ \\
\hline $\begin{array}{l}\text { Unexplaine } \\
d\end{array}$ & $0.204^{\star \star *}$ & $0.335^{\star \star \star}$ & $0.268^{\star \star \star}$ & $0.342^{\star \star \star}$ & $0.362^{\star * *}$ & $0.343^{\star \star \star}$ \\
\hline \multicolumn{7}{|c|}{ Part 2: Average hourly wage rate } \\
\hline Men & $3.184^{\star \star \star}$ & $3.041^{\star \star \star}$ & $3.129^{\star \star \star}$ & $3.120^{\star \star \star}$ & $2.993^{\star \star \star}$ & $3.087^{\star \star \star}$ \\
\hline Women & $3.129^{\star \star \star}$ & $3.029^{\star \star \star}$ & $3.091^{\star \star \star}$ & $3.067^{\star \star \star}$ & $2.998^{\star \star \star}$ & $3.050^{\star \star \star}$ \\
\hline Difference & $0.055^{\star \star \star}$ & 0.012 & $0.039^{\star \star \star}$ & $0.054^{\star \star \star}$ & -0.005 & $0.037^{\star \star \star}$ \\
\hline Explained & $0.022^{\star *}$ & $0.038^{\star * \star}$ & $0.027^{\star * \star}$ & $0.026^{\star \star \star}$ & 0.037 & $0.032^{\star * \star}$ \\
\hline $\begin{array}{l}\text { Unexplaine } \\
\text { d }\end{array}$ & $0.033^{\star * *}$ & $-0.050^{* *}$ & $0.012^{* \star *}$ & $0.028^{\star \star \star}$ & -0.032 & $0.005^{\star \star *}$ \\
\hline
\end{tabular}

${ }^{* * *},{ }^{* *},{ }^{*}$ indicates significant at $1 \%, 5 \%$ and $10 \%$ level respectively.

As evident from the findings from this decomposition, based on the average of the results obtained when the women and men wage structures are employed as the nondiscriminatory norm, raw gender differentials exist in income and wage in all regions considered in this analysis. In general, differences were substantially higher for income levels in all regions than was the case for wage rates. This is mainly due to Australia's non-discriminatory wage determination policies and a higher proportion of part-time women workers than men (which results in lower income for women). Almost all of the coefficients for income differences have been found to be statistically significant at the 10 per cent level or higher.

In the case of average weekly income, raw differences are found to be higher in regional areas in both states. In Victoria, differences were about 38.7 percent in regional areas compared to 35.2 percent in Melbourne and 35.9 in the state. Similarly, in NSW, regional areas produced raw differences of about 37.3 percent where Sydney and the entire NSW state reported 25.2 percent and 30.5 percent differences respectively. The BlinderOaxaca decomposition revealed that only a small proportion of each raw difference was 
attributable to a difference in the endowments of the men and women in terms of educational qualifications, age etc. The remaining parts can be attributed to the difference in coefficients, and may be interpreted as an 'unexplained' part or simple discrimination. Discrimination against women appeared to be highest in regional Victoria where the degree of unexplained difference was 36.2 percent - only about 2.5 percent of raw differences could be explained by endowments. The situation in Melbourne was similar with unexplained discrimination of 34.2 percent and an even smaller proportion (about 1.0 percent) of raw differences being explained by endowments. However, the results obtained for Melbourne and other Victoria need to be interpreted with caution as the coefficients related to explained or the endowment component were not found to be statistically significant. The situation in the state of NSW was quite different where the level of unexplained discrimination against women workers seems to be significantly higher in regional areas compared with Sydney - 33.5 percent for regional NSW against 20.4 percent for Sydney. The proportions of raw differences explained by endowments were also much higher in NSW - about 3.8 percent for regional NSW and 4.7 percent for Sydney. This finding speaks to a number of issues including access to fewer hours of work and lower income-generating asset ownership amongst women - particularly nonmetropolitan women. Thus, as per the Blinder-Oaxaca decomposition analysis raw discrimination exists against women workers in terms of earning average weekly income in all labour markets considered here. Excluding endowments 'unexplained' levels of discrimination were higher in regional areas than the metropolitan cities of their respective states. This city-region difference was significantly higher in NSW than Victoria although the absolute level of discrimination was higher in Victoria in both markets region and the city.

As the second part of Table 6 reveals, levels of raw wage differences were substantially lower compared with income mainly due to non-discriminatory wage policies followed in Australia. The coefficients were found to be consistently significant only for metropolitan cities, and not for the regions. Thus an effective comparison could not be made between cities and regions on the basis of the Blinder-Oaxaca decomposition results. It is possible that due to lack of skilled professional workers in several industries/sectors in regional areas higher wages (higher than award rates) were offered to attract employees. Usually men choose to accept such higher pays in regional and remote locations, and that generates gender discrimination in wage rates when regions are aggregated. Both Sydney and Melbourne labour markets revealed low and similar type of discrimination against women workers when average hourly wage rates were considered. Estimated coefficients were not found to be satisfactory for RVIC. This may possibly indicate lack of consistent patterns in wage rates between men and women. Victoria is a smaller state as compared to NSW, and regional areas are apparently more integrated to Melbourne due to shorter distances. Information flow between regional locations and the state capital is faster which leads to faster identification of discriminations and the initiation of formal or informal action to remedy a discriminatory situation. 


\section{Conclusion}

This research intended to analyse gender and location issues together in the context of the Australian labour market. Using CURF data of the 2006 Census this paper analysed the determinants of weekly incomes and hourly wage rates by gender in two major Australian metropolitan cities (Sydney and Melbourne) and the respective regional areas of each state (regional NSW and regional Victoria).

The results of quantitative analysis revealed three sets of differences. The first and foremost is gender discrimination which is the major focus of this research. The research found substantial evidence of positive discrimination against women in all labour markets. This was particularly prominent in weekly incomes. The extent of discrimination varied between about 20.4 percent in Sydney and 36.2 percent in regional Victoria in the case of average weekly income. This high discrimination may be attributed to a number of factors such as higher part-time work, greater participation of women in low paying jobs and a lower ownership of income earning assets by women. For obvious reasons the extent of wage discrimination was significantly lower than for income discrimination. This varied between 2.8 percent in Melbourne and 3.3 percent in Sydney. Wage discrimination in regional areas remained statistically unclear in both states studied.

The second type of difference observed is the discrimination between locations - cities and regional areas. The level of discrimination against women was consistently higher in regions than in metropolitan cities in both states mainly due to limited job opportunities and lower ownership of income earning assets by women in regions. Thus, women workers in regional areas were the most discriminated against. This may have a serious impact on regional development in Australia. The third level of difference is between two states studied here. Victoria revealed a much higher level of discrimination against women than NSW. The differences were marginal in regional areas, but substantial in cities - the extent was 34.2 percent in Melbourne against 20.4 percent in Sydney for weekly incomes. Being larger in size, more diversified and with more immigrants Sydney possibly had more quality job opportunities for women than Melbourne. The findings also confirm the commonly held belief that Victoria is a more conservative state in Australia as compared to other states. In the case of hourly wages, Sydney revealed a slightly higher level of discrimination than Melbourne - possibly due the existence of a larger proportion of workers in the unorganised market.

This research confirms that gender discrimination exists in major Australian labour markets and finds that the degree of discrimination is higher in regional areas than in their associated metropolitan areas. The findings are broadly in line with several earlier research (Mallik et al 2014; Li and Miller 2012; WRC 2010; Watson 2010). At the same time, this research identified a number of factors that impacted weekly incomes and hourly wages and assessed how these factors impacted differently for men and women across metropolitan and regional areas. Although this research included observations 
from two states in Australia, the results can be generalised to a great extent as these two states together accounted for about 57.1 percent of the Australian population.

\section{References}

AUSTRALIAN BUREAU OF STATISTICS (ABS) (2006) Census of Population and Housing. Catalogue no. 2068.0, Australian Bureau of Statistics, Canberra.

AUSTRALIAN BUREAU OF STATISTICS (ABS) (2004) Education \& Work: Higher Education Graduates in the Labour Market. Australian Bureau of Statistics, Canberra.

http://www.abs.gov.au/AUSSTATS/abs@.nsf/2f762f95845417aeca25706c00834efa/e1a27d207c960 e79ca256e9e00286295

AUSTRALIAN BUREAU OF STATISTICS (ABS) (online) Community Profiles. Census Data 2006, Australian Bureau of Statistics, Canberra, www.censusdata.abs.gov.au/.

AHMED, S. and MAITRA, P. (2010) Gender Wage Discrimination in Rural and Urban Labour Markets of Bangladesh. Oxford Development Studies. 2010, Vol. 38, No. 1, 83-112.

ASPLUND, R. and NAPARI, S. (2011) Intangibles and the Gender Wage Gap: An Analysis of Gender Wage Gaps Across Occupations in the Finnish Private Sector. Journal of Labour Research. 2011, Vol. 32, 305-325.

BAUM, S.; BILL, A. and MITCHELL, W. (2008) Employment Outcomes in Non-metropolitan Labour Markets: Individual and Regional Labour Market Factors. Australasian Journal of Regional Studies. 2008, Vol. 14, No. 1, 5-25.

BRADLEY, S. and TAYLOR J. (1991) An Empirical Analysis of the Unemployment Duration of SchoolLeavers. Applied Economics. 1991, Vol. 24, 89-101.

CUNNINGHAM, M. and DAVIS, K. (2011) Labour Market Outcomes in Regional Australia. Bulletin. September Quarter, Reserve Bank of Australia, 1-8.

DIXON, R. and SHEPHERD, D. (2011) State and Territory Employment and Unemployment Patterns in Australia. Australian Economic Review. 2011, Vol. 44, No. 2, 196-206.

EDIN P. A. (1989) Unemployment Duration and Competing Risks: Evidence from Sweden. Scandinavian Journal of Economics. 1989, Vol. 91, No. 4, 639-653.

FLORIT E. F. and LLADOSA L. V. (2007) Evaluation of the Effects of Education on Job Satisfaction: Independent Single-equation vs. Structural Equation Models. International Advances in Economic Research. 2007, Vol. 13, No. 2, 157-170.

GASTEEN, A. and HOUSTON, J. (2007) Employability and Earnings Returns to Qualifications in Scotland. Regional Studies. 2007, Vol. 41, No. 4, 443-451. .

GILBERT, A.; PHIMISTER, E. and THEODOSSIOU, I. (2003) Low Pay and Income in Urban and Rural Areas: Evidence from the British Household Panel Survey. Urban Studies. 2003, Vol. 40, No. 7 $1207-1222$.

HOWARD, D. (2005) Modelling Regional Labour Market Performance in Australia Using Twenty-Five Years of Intercensal Data. International Journal of Employment Studies. 2005, Vol. 13, No.2, 69-88.

JANN, B. (2008) A Stata implementation of the Blinder-Oaxaca decomposition. ETH Zurich Sociology Working Paper No 5. 
JOACHIM, M. and ALISHER, A. (2007) Wage Inequality, Reservation Wages and Labour Market Participation: Testing the Implications of a Search-theoretical Model with Regional data. International Regional Science Review. 2007, Vol. 30, No. 2, 120-151.

LAZARO, N.; MOLTO, M. L. and SANCHEZ, R. (2000) Unemployment Determinants for Women in Spain. Labour. 2000, Vol. 14, No. 1, pp. 53-78.

LI, IAN W. and MILLER, P. W. (2012) Gender Discrimination in the Australian Graduate Labour Market. Australian Journal of Labour Economics. Vol. 15, No. 3, 167-199.

LIU, AN and NOBACK, I. (2011) Determinants of Regional Female Labour Market Participation in the Netherlands. Annals of Regional Science. 2011, Vol. 47, No. 3, 641-658.

LOVELL, P. (2000) Race, Gender and Regional Labour Market Inequalities in Brazil. Review of Social Economy.2000, Vol. LVIII, No. 3, 276-93.

MALLIK, G, BASU, P K, HICKS, J, and SAPPEY, R (2014) Do the Determinants of Employability and Earnings Returns Produce Similar Outcomes in Metropolitan and Regional Labour Markets?: The Case of NSW in Australia. Regional Studies. 2014, Vol 48, No. 10, 1706-1718.

MINCER J. (1974) Schooling, Experience and Earnings. Columbia University Press: New York.

NARENDRANATHAN W. and STEWART M. B. (1993) Modelling the Probability of Leaving Unemployment: Competing Risk models with Flexible Baseline Hazards. Applied Statistics.1993, Vol. 43, No. 1, 6368.

SYED, J. and MURRAY, P. (2009) Combating the English Language Deficit: The Labour Market Experiences of Migrant Women in Australia. Human Resource Management Journal. 2009, Vol. 19, No. 4, 413-432.

WANG, Q. (2010) Immigration and Ethnic Entrepreneurship: A Comparative Study in the United States. Growth and Change. 2010, Vol. 41, No. 3, 430-458.

WANG, Q. (2008) Race/Ethnicity, Gender and Job Earnings Across Metropolitan Areas in the United States: A Multilevel Analysis. Urban Studies. 2008, Vol. 45, No. 4, 825-843.

WATSON, I. (2010) Decomposing the Gender Pay Gap in the Australian Managerial Labour Market. Australian Journal of Labour Economics. 2010, Vol. 13, No. 1, 49-79.

WORKPLACE RESEARCH CENTRE (WRC) (2010) Profile of Women's Employment in NSW: Trends and Issues. Report prepared for the Office for Women's Policy NSW Department of Premier and Cabinet. 